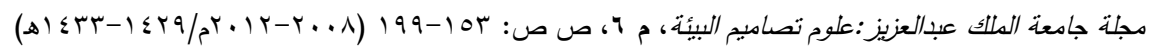
DOI: 10.4197 / Evn. 6.8

\title{
التخطيط للسيطرة المكانية
}

\section{أيمن محمد إسماعيل}

قسم التخطبط الحضري والإقلبيس، كلية تصامبم البيئة جامعة الملك عبد العزبز،

جدة، المدلكة العربية السعودية

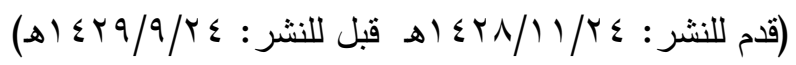

المستخلص: تعرض هذه الورقـة كيف يمكن للتخطيط العمراني أن

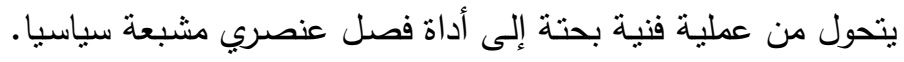

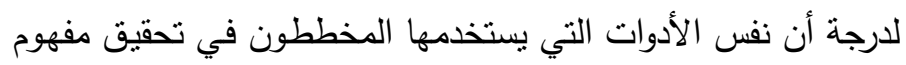

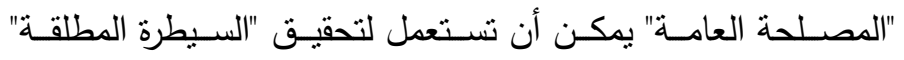

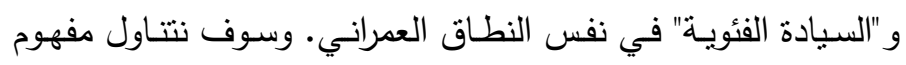

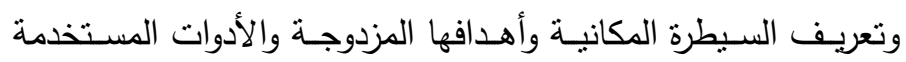

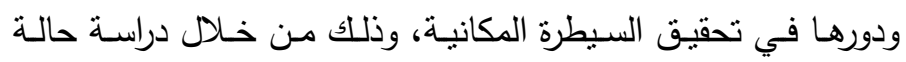

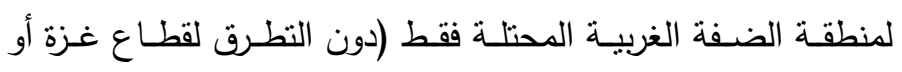
القدس). لإبراز هذه الحالة وذلك بسبب مساحتها وتواصلها المكاني مما يسمح بالتحليل الجغرافي. والهـدف هـو محاولــة إيجـاد علاقـة أو نمـوذج بـين تطويـع

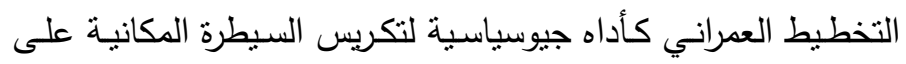

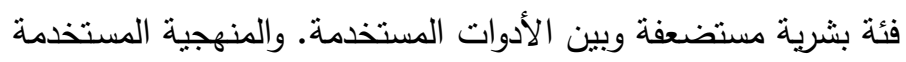

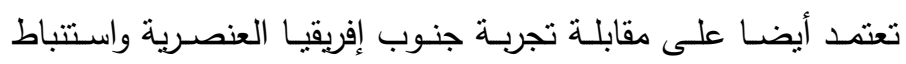

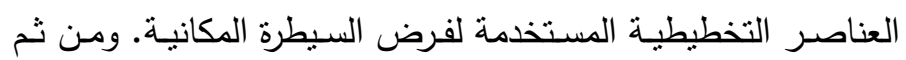


تتبع وضعية الضفة الغربية عسكريا وأيديولوجيا والروئية الاستراتيجية

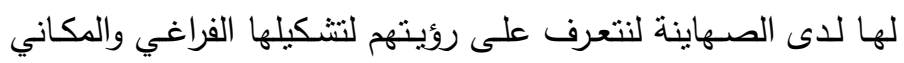

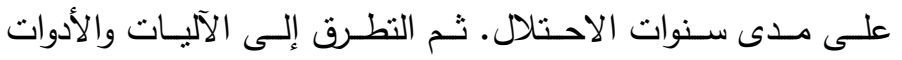

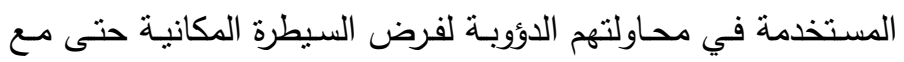

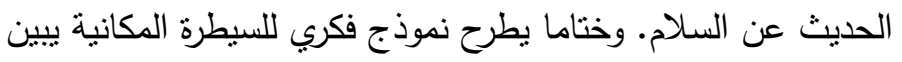
عناصرها ودور التخطيط في تحقيقها. وقد تم الاعتماد على البيانات من مصادر ثانوية، وذللك نظرا لتعقيدات تتبع بيانات أولية.

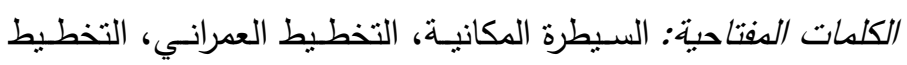

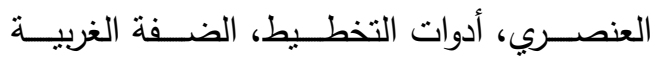

المحتلة.

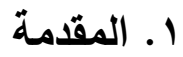

الأصل في مصطلح السبطرة المكانيـة (spatial dominance) أنـه يندرج تحت

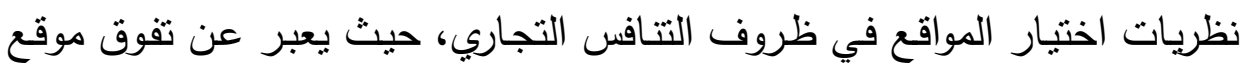

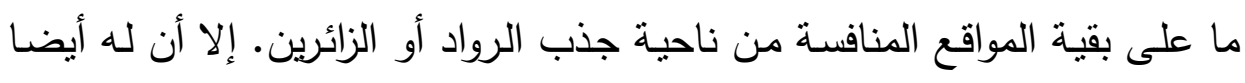

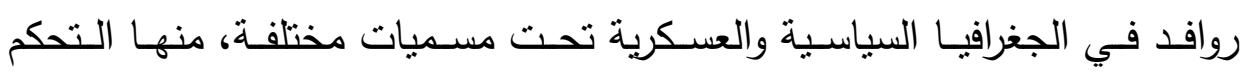

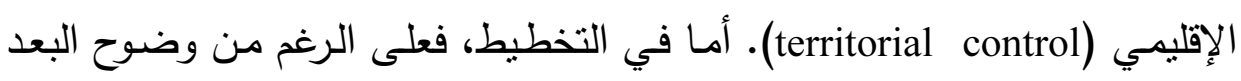

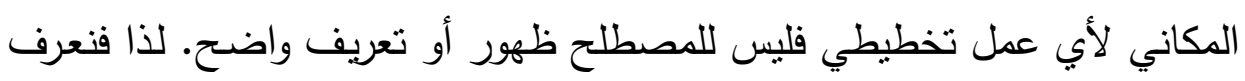

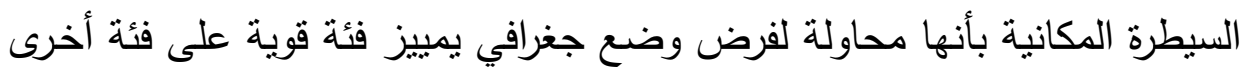

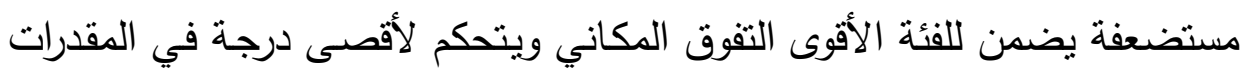

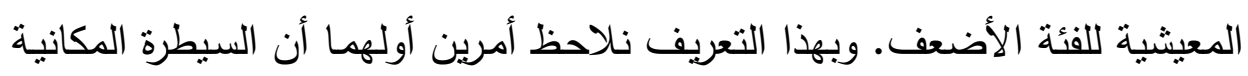

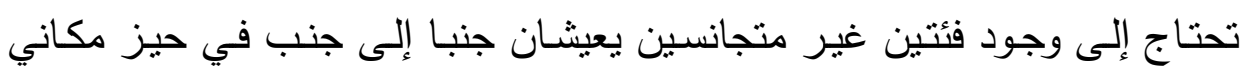

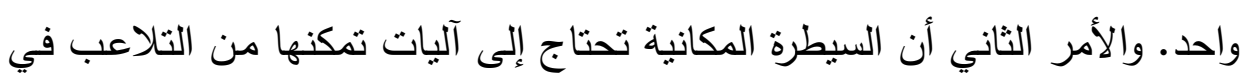

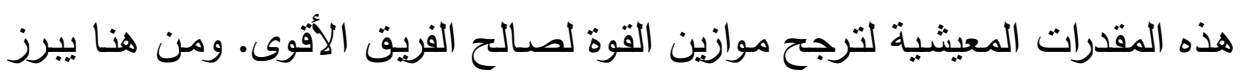

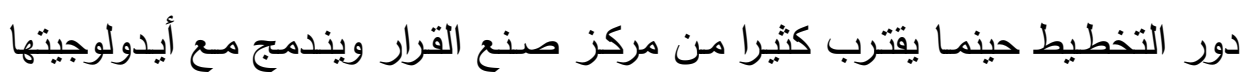


السياسية. ولكن نفرق هنـا بـين التخطيط العمراني المتعدد الذي يرمسي للسيطرة المكانية بتعريفها المسبق، وبين الوضع الاقتصادي الطبيعي الذي ينتج عنه تباين

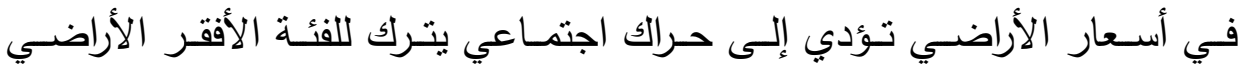
الرخيصـة وغير المرغوب فيها. بهذا نستنتي الجيتوس (Ghettos) في الولايـات المتحدة التي استوطن بها أقليات ملونـة. وبالتالي يتبقى لنا عدد بسبط من الدول أبرزها دولة جنوب إفريقيا وناميبيا في الفترة من 19 1 إلى ؟9 9 (م. ونركز على هذا المثال باعتباره نموذجا في الفكر التخطيطي العنصـري المبني على الفصل المكاني بين الإثثيات والأعراق.

\section{r. التخطيط في جنوب إفريقيا}

ظهرت التفرقـة العنصـرية رسـيا في جنـوب إفريقيـا عـام 9 امهام، ومعها مجموعة كبيرة من التشريعات لضمان تطبيقها. وامتدت هذه الحالة بالضرورة إلى

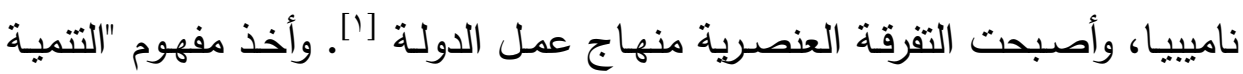
المنفصلة" العنصري إلى غايته، ضامنا بقاء توفر العمالة الرخيصـة، بينما انشخلت الحكومـة بقـع الأفارقة السود، وفرت الرفاهية للأقلية الأوروبية. وظهرت تفاوتات في كلّ مجالات الحياة السياسية والاقتصادية والاجتماعية حتى طالت المخططين. فتذكر لينسـاي بريمنر أستاذة التخطبط في جنوب إفريقيـا أن المخططين والمعدـاريين في هذه الحقبـة كـانوا أدوات للدولـة ليعكسوا في مخططـاهم الفكر الرسـمي السـائد. وقد اسـتخدموا لأغراضـهم أدوات تسـميها لندسـاي أدوات "التحكم والإذلال". وتمتلت بعض هذه الأدوات في طريقة ترسيم الحدود والحواجز داخل الحيز المكاني الواحد، وتجميع السكان في جيوب وكنتونات والسماح لهح بالحكم الـذاتي، وتهمـيش نشـاطهم الاقتصـادي الـذاتي وربطـهـ بالعمالـة الرخيصـة داخـل أراضي الأقلية البيضاء. ثم ابتكار العديد من آليات التحكم الإداري ذات الوجهين،

وجه لكل فئة: مثل قوانين البناء والتخطيط وأنظمة المرور والتصاربح وغيرها [؟ّ] 
وقد انعكس هذا الفكر على مستويين. الأول محلي على مستوى المستقرات

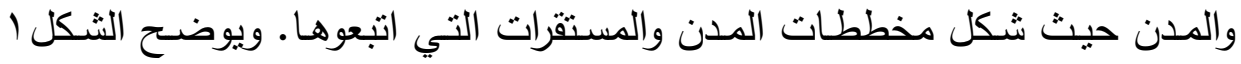
التخطيط النمطي لإحدى هذه المسنقرات. ويقال أن الفكر التخطيطي في جنوب

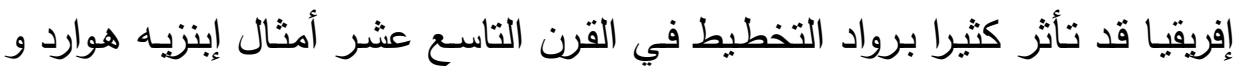

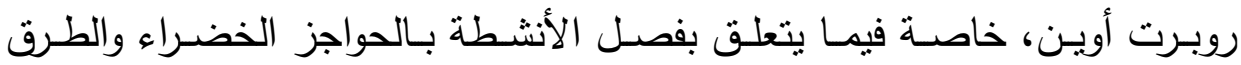

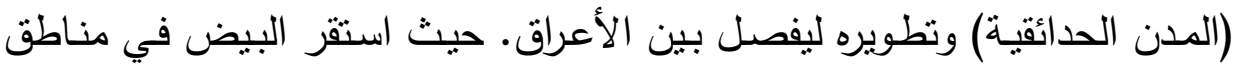

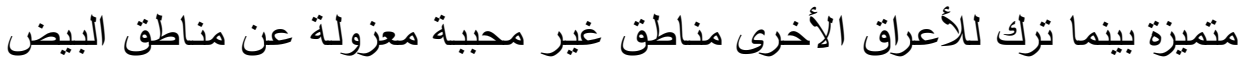
بحواجز طبيعيـة وصـناعية تفصلهم عن بعض. و نلاحظ مـن المخطط كيفيـة

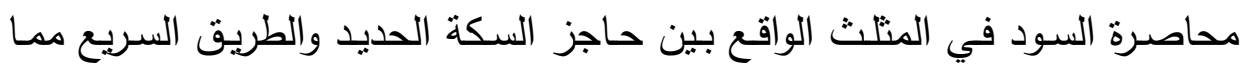

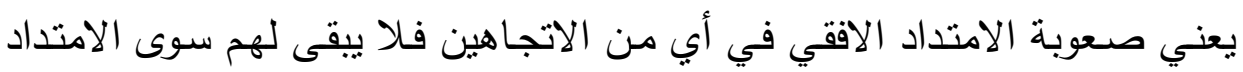

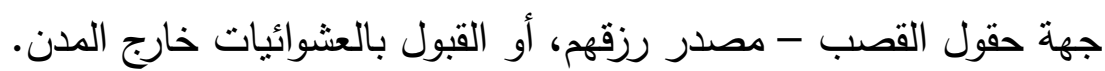
أمـا على المستوى الثناني وهو الإقليمي فقد عمد المخطط العنصري في

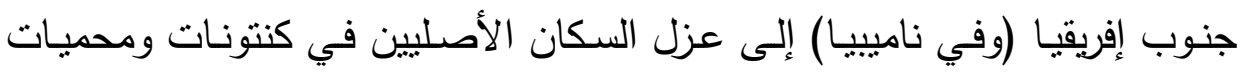

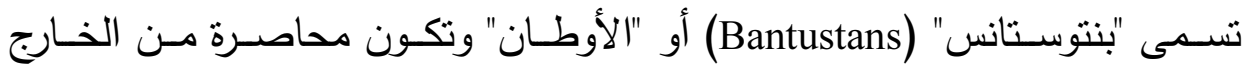

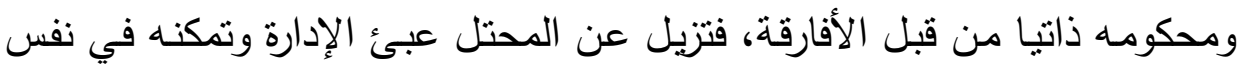
الوقت من التحكم في نموه الجغرافي عن طريق ترسيم حدود لله ومحاصرته بطرق

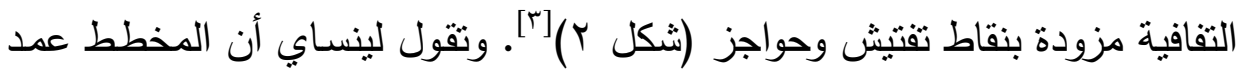
إلى إعادة إحياء النعرة القبلية لاى السود بتخصيص البنتوستانس لكل قبيلة بمزايا متباينة، فبعضها لله صـاحيات محدودة من الحكم الذاتي والآخر لـه كيان يشبه

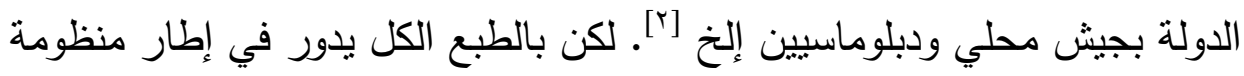
خدمية تصب في العمالة الرخيصة لدى البيض ("). 
وقد ظهر ذلك جليا في نمط التوزيع المكاني لهذه المستقرات. فنجد هذه

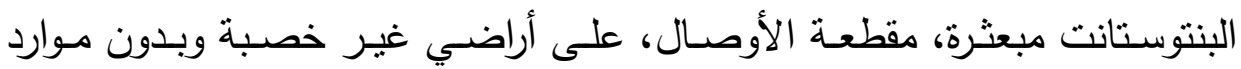
تقريبا. أما إداريا، فكانت تحكم هذه البنتوستانات مجموعة من التشريعات والقوانين المفصلة لصالح البيض ولكنها أيضـا قابلة للتغيير عند الضرورة ويختار لحكمهم مواطنين سود من ذوي الولاء للبيض("* لـ

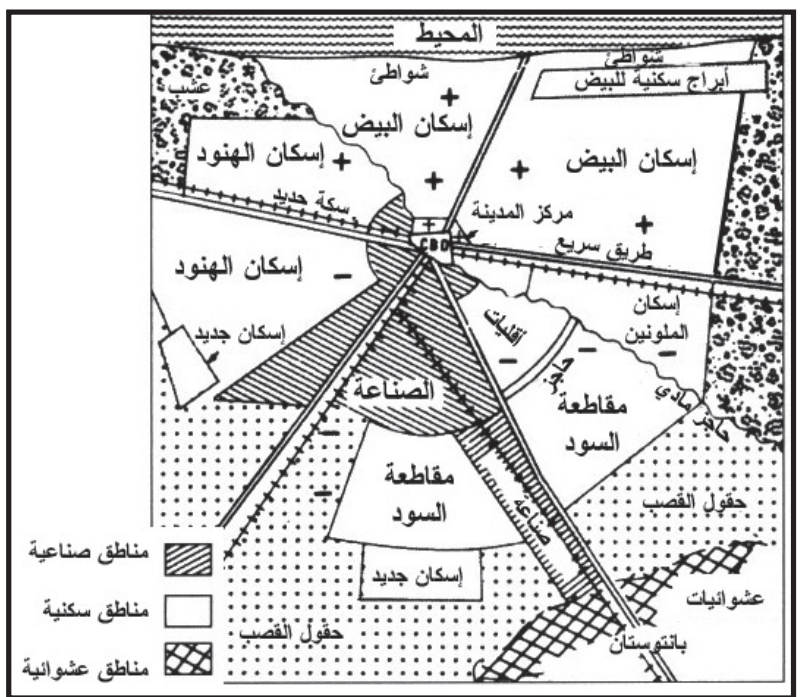

شكل 1. التخطيط التقليدي لمدن جنوب إفريقيا إبان الحقبة العنصرية [r]

والمـدقق فـي خلاصـة هــذه السياسـات يلاحــ أولا أن المخطـط نشـبع

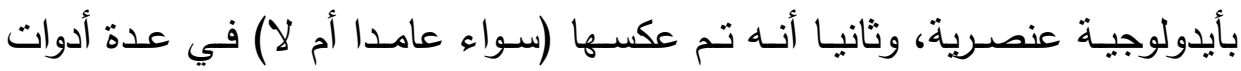
تخطيطية لفرض واقع سياسي يقهر السود مكانيا واقتصـاديا ويضدن تفوق وسيطرة الأقلية البيضاء على المستوبين المحلي والإقليمي. هذه الأدوات يمكن إيجازها فيما

1 بناء مستقرات جديدة.

r. تحديد حيز للنمو العمراني بوسائل طبيعية وصناعية.

(**) على سبيل المثال قضية الحدود إذا ما ظهرث مناجم أو موارد اقتصادية جديدة فكان يتم تعديلها لتضم إلى التى المناطق البيضاء. 
r. تنظيم استعمالات الأراضي.

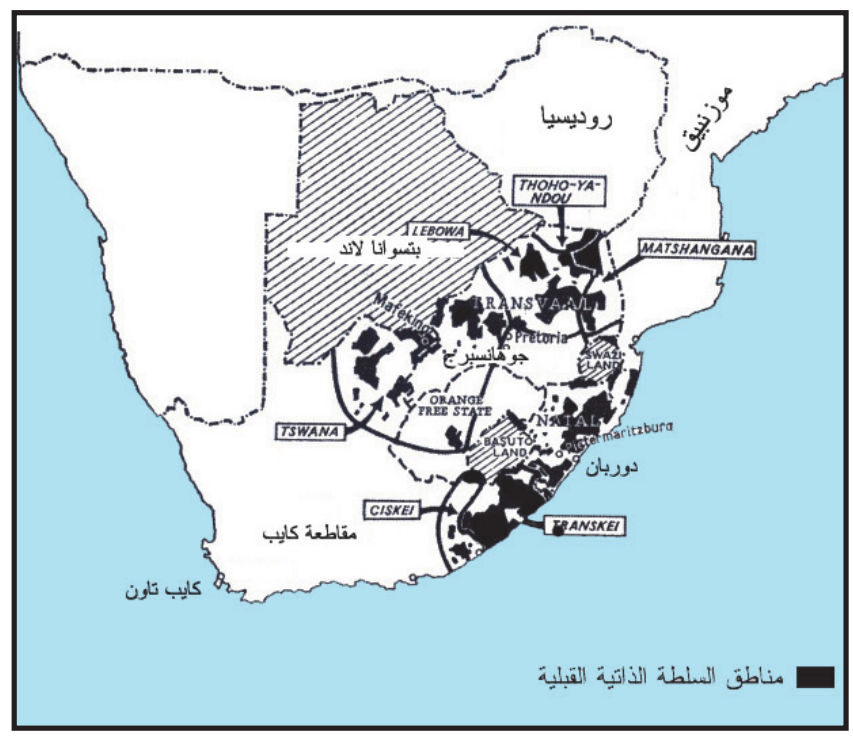

شكل (r). التقسيم القبلي لمناطق السود في جنوب إفريقيا [־]

ء. صـياغة قوانين للتخطبط العمرانـي لا تسـتند إلى واقع عـادل وتعـديل

القانون واللوائح.

0. استخدام الحدود العمرانية بوضوح للفصل.

7. شق شبكات للطرق تخدم فئة بعينها.

هـذه الأدوات شـائعة، وليسـت مقصـورة على تخطـيط عنصـري أو غيـره، ويسـتخدمها المخطط عـادة لإحداث أهداف تتمويـة واضـحة ذات مـردود إيجـابي

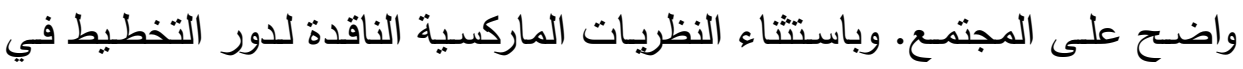
النظام الرأسمالي، فلم يرد - حتى فيها - وجود أهداف خفيـة يسعى من خلالهـا

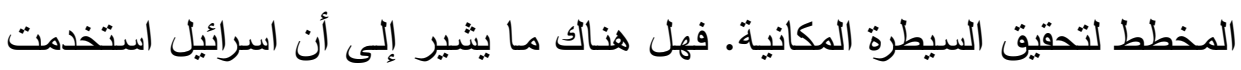
نفس هـذه الأدوات فـي فـرض واقـع بتيح للاسـرائيليين تفـوق وسـيطرة وسياسـية استراتيجية على الأرض بينما يحد من قابلية الفلسطينيين؟ وهل تتطبق حالة جنوب 
إفريقيا رغم إختلاف بعض الأطر كغياب العدو الخارجي أو الهجرة من الخارج أو التتازع في شرعية الاحتلال.

يـرى الباحـث أن الأمـر ذو شـقين، أولهمــا يتعلـق بالأهـداف المؤسسـية للمنظومـة التخطيطية ومدى ارتباطها بالأيدولوجية للنخبة الحاكمـة، والثاني مرتبط

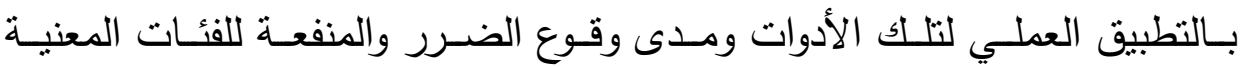
بالدراسة. وهذا تحديدا ما سوف نتناوله بالأدلة من خلال التركيز على دراسـة حالة التخطيط في الضفة الغربية المحتلة. والسبب في ذلك التركيز ليس اعترافا بشرعية احتلال بـاقي الأراضـي بـل للوضـعية الخاصـة للضفة حتى في شـرع الإسـرائيلين أنفسهم. فالضفة الغربية أراض محتلة حتى عند الإسرائيليين ولا تتطبق عليها باقي القوانين الإسرائيلية. إلا أن هذا لا يمنع أن لهم أهدافا طويلة الأجل فيها. وقد يثار تسـاول عن مدى انطباق حالة جنوب إفريقيا رغم اختلاف بعض الأطر كغياب العدو الخارجي والهجرة من الخارج والتتازع في شرعية الاحتلال. فالإجابة أن هذه المتغيـرات حتمــا تعظم مـن الحاجـة لفـرض سـيطرة مكانيـة فالحالـة العدائيـة بـين إسرائيل وجيرانها تستوجب أكثر تأمين عازل استراتيجي (buffer) كما اتضح من خطة آلون وتطوراتها. كما لوحظ ذللك في نظرتها لسيناء إبان الاحتلال. أما الهجرة من الخارج فترفع الحاجة لتوفير أراضي للتوطين والتتمية. والتتازع يؤدي للإسراع في فرض أمر واقع خشية أن تدور الدائرة.

\section{r. الضفة الغربية}

سقطت الضفة الغربية والقدس في أيدي الإسرائيليين في يونيو عام 9 أو ـ

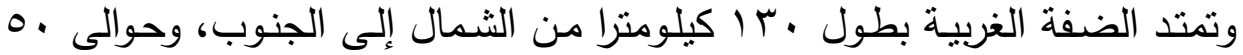

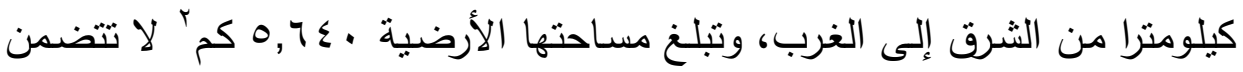

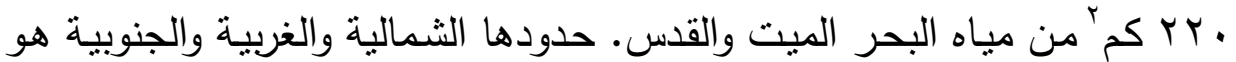


الخط الأخضـر (خط الهـنـة لعـام 9ء9 1). وفي الشـرقية يقع نهر الأردن الذي يصب في البحر الميت، وبعده المملكة الأردنية (شكل ب). ويمكن تقسيم الضفة الغربية - لغرض التحليل لا أكثر - إلى أربعة مناطق. ثثلاثة منها شرائح طولية تمتدّ من الثـمال إلى الجنوب، والرابعـة منطقة القدس. فالثـريط الثرقي يتضمّن منطقـة وادي الأردن وشـواطـئ البحـر الميــ، بالإضــافة إلـى سلسـلة المنحـدرات الجبلية الشرقية التي تشطر كامل الضفة الغربية من الشمال إلى الجنوب. وتحتوبي

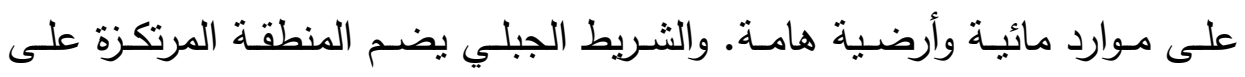

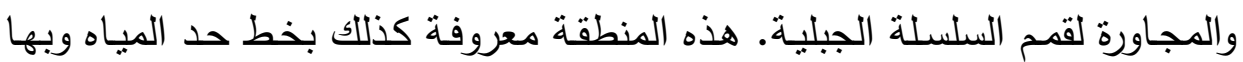
أكبر طربق (رقم • ؟) الذي يربط العديد من المستوطنات الإسرائيلية. أما منطقة شربط التلال الغربية فتضضمّن المنحدرات الغربية للسلسلة الجبلية، وتمتد إلى الخط الأخضرغربا. ونظرا لقربه من المدن الكبرى داخل الخط الأخضر فقيه يستوطن

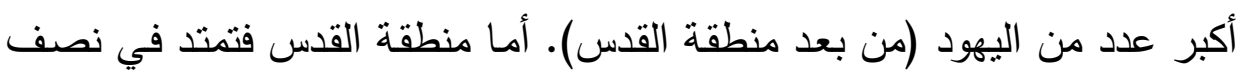
قطر عريض حول القدس الغربية ولخصائصـها الفربدة تستـدعى إهنمامـا خاصـا ليس مجالها هذا البحث.

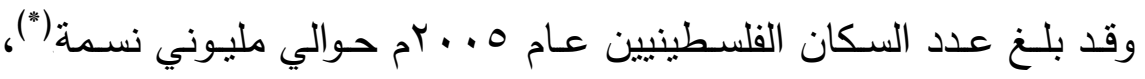
يتركز YV ٪ منهم في المدن والقرى في غرب ووسط الضفة. أكبر المدن في الفئة الحجمية الأولى هي القدس الثرقية ، ونابلس والخليل، وفي الفئة الثانية رام الله

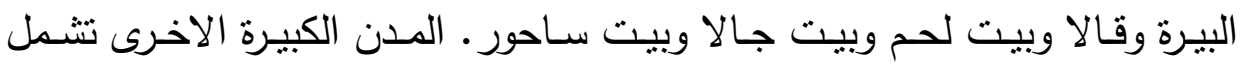
طولكرم وقلقيلية (الخط الاخضر ) وجنين في الثمال. وبقية السكان يعيشون في حوالى • 0ـ قرية شديدة التقارب (المسافة بين مراكز القري لا تزيد عن 0,ب كلم في المتوسط). معظم القرى تتمو نموا سربعا في عدد السكان في السنوات الأخيرة، وكلها تحيط بها أراض بملكها ويزرعها أهـالي القريـة. ويزبـد الفلسطينيون سـنويا 


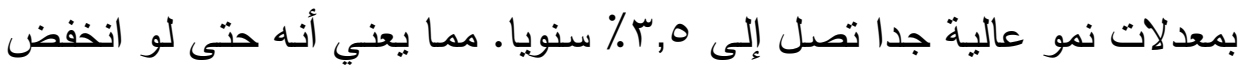

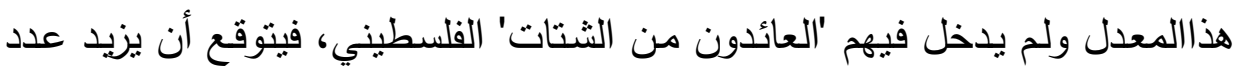
السكان بمقار النتث في غضون • ( سنوات. لذا فإن التكدس السكاني في القرى وفي مخيمات اللاجئين وفي المدن مرتفع جدا.

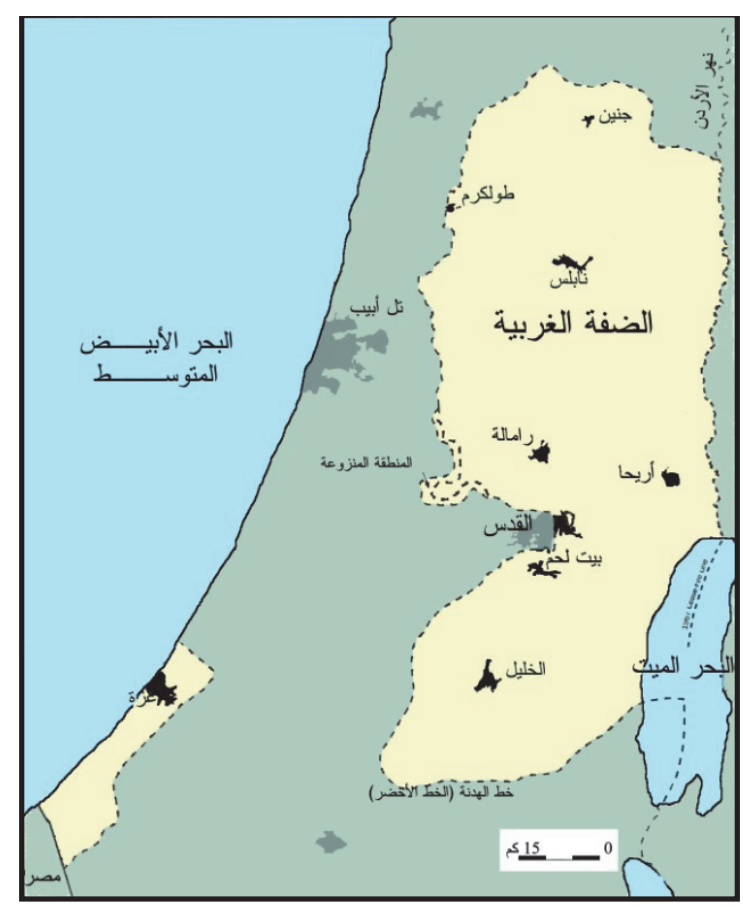

شكل r. خريطة الضفة الغربية.

وفي الوقت الذي زادت فيه أعداد الفلسطينيين منذ الاحتلال بحوالي سبعة

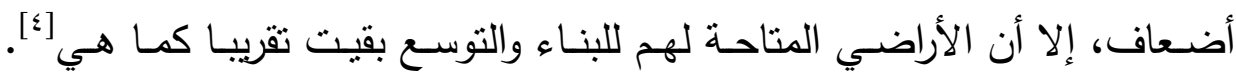

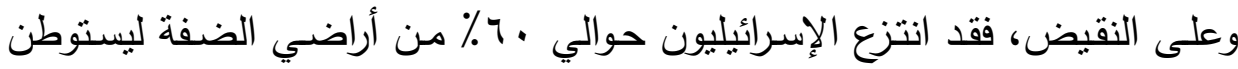
عليها عدد لا يزيد عن ربع السكان الفلسطينيين ويحززوها لنموهم "الطبيعي" والذي في الأسـاس لا تتجاوز نسبته ب ٪ على أعلى تقدير • وعليه فـإن كل مستوطن 
إسرائيلي يأخذ (من حيث المساحة) مكان • ؛ فلسطيني اليوم، وسوف يأخذ مكان

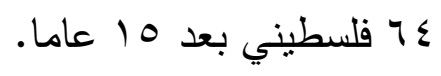

هذا الوضع الظالم لم يكن فقط وليد سلطة احتلال قهري. ولكن المثير أنه

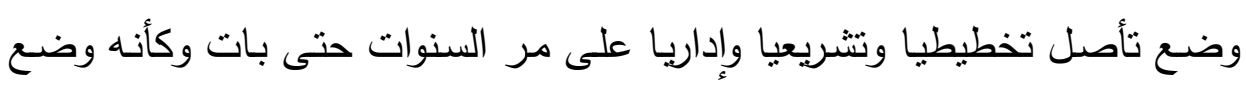

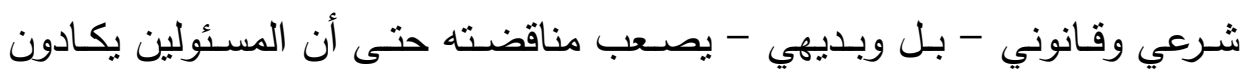

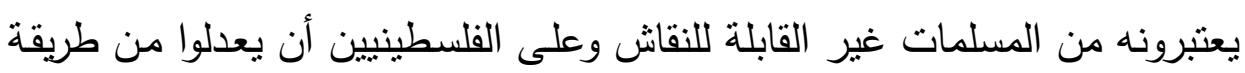

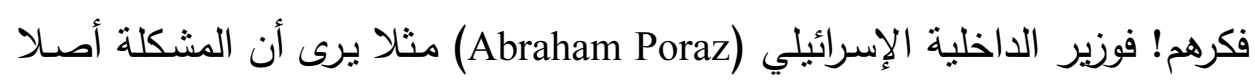

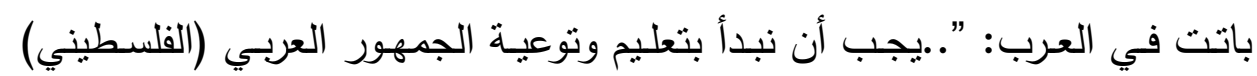

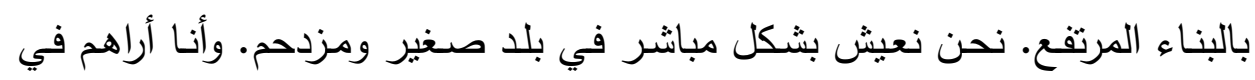

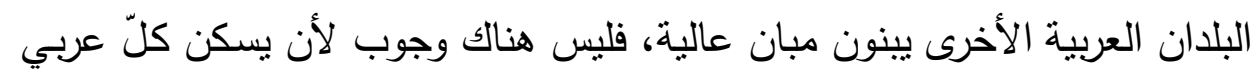

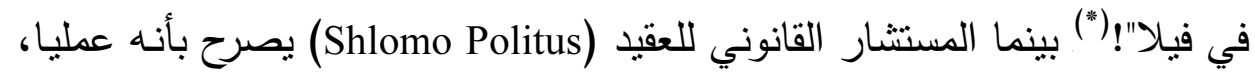
هذه لم تعد قضية. لن يكون هناك المزيد من رخص البناء للفلسطينيين"("*"). ومن هذا المدخل يثير التساؤل حول كيفية تحول وضع مكاني غير متزن بوضوح ويناقض كافة الأسس التخطيطية المعروفة إلى حالة تبدو مستقرة ولها مرتكزات تخطيطية.

\section{تطور التخطيط في الضفة الغربية}

تعكس الخريطة الحالية للضفة الغربية التحول الجذري الذي حدث للمنطقة

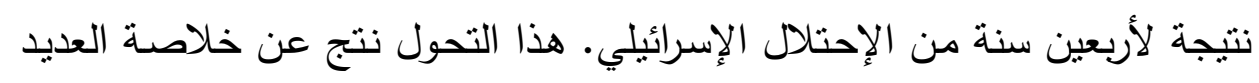

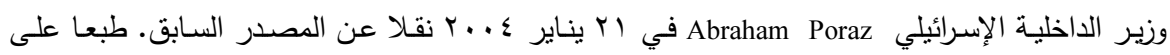

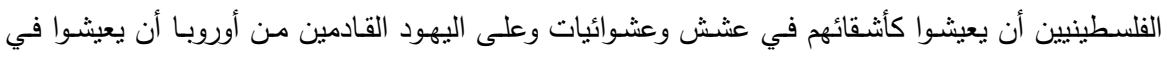

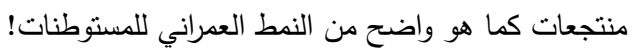

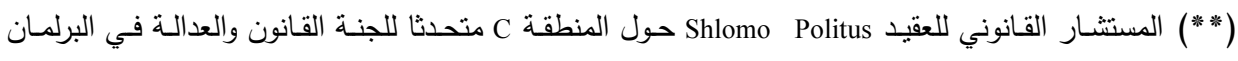

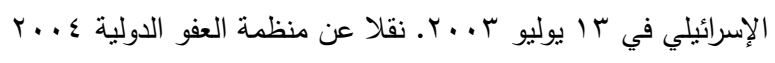


من الخطط الإستيطانية الإقليمية والمحلية المدعومـة بعشرات التشربعات واللوائح التي تجيز وتذلل بطريقة منظمة عملية تقسيم الضفة الغربية لمناطق بها عشرات

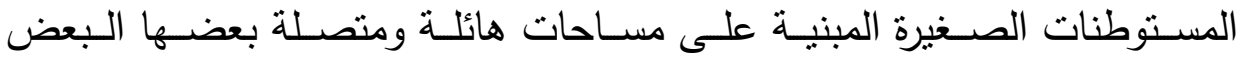
و "بإسرائيل"، بواسطة شبكة معقدة من الطرق، تعزل وتحاصر المناطق الفلسطينية. ورغم أن الوضع لم يكن قطعا وليد ليلة وضحاها، ولا نتيجة لأمر عسكري مباشر إلا أنـه بالفعل تم استخدام تدريجي لأدوات تخطيطيـة شـائعة لإعـادة رسم خريطة للمنطقة يبدو من خلالها صورة يصعب أولا عكسها (ما قبل الاحتلال)، وثانيا وفي نفس الوقت وكأنها نتاج لفكر تخطيطي منطقي يفرض على الأقل احترامه. بداية - وعلى عكس ما هو متداول عربيا - لم تكن الضفة الغربية ضمن حدود المخططسات الأوليـة لمؤسسي الدولـة. حتى أن بـن جوريون كان أكثر من راض بنتيجة حرب 9 \ام التي ضمنت لإسـرائيل مسـاحة أكبر من حدود قرار

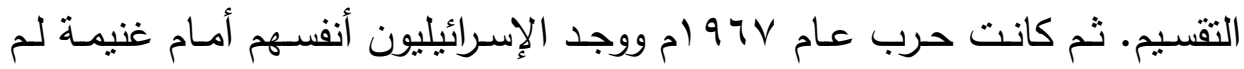
يعدوا لها. فأثتاء الثـهورِ التي تلكت الحرب لم تكن لدى الحكومـة الاسـرائيلية أي التي سياسـة واضـحة بخصسوص المستوطنات في الضـفة الغربيـة. وكان الرأي الأولي لأغلب أعضـاء الحكومـة أَن تستخدم هذه الأرض كورقة مسـاومة في المفاوضـات

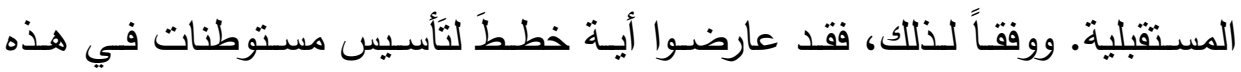
المنطقة. ولكن سرعان ما تلاشى هذا الرأي تحت وطأة الضـوط التي مورست من مختلف مجموعـات الضـغط الدينيـة والسياسية وأصـحاب المصـالح، حتى أنشـأت "Kfar Etzion" - أول مسـتوطنة اسـرائيلية- في الضـفة الغربيـة في سـبتمبر - م) $97 \mathrm{~V}$

وقد ساعد التطرف الديني في تتامي نفوذ أصحاب هذا الرأي في استغلال الضفة المحتلة في الاستيطان. فقد فسر نصر إسرائيل في حربٍ VT 97 ام لدى 
بعض الدوائرِ اليمينيـة بصـورة دينيـة على أنـه "بدايـة الخـلاص" الموعـد بـه في

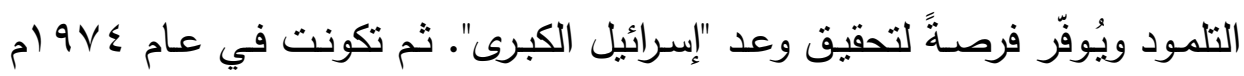
جماعـة "كتلـة المؤمنين" تحت القيادة الروحيـة للحبرِ يهودا كووك. وكان الهدف الفـوري للحركـة أَن تجبـر الحكومسةَ علـي تَأسـيس مستوطنات منتشـرة على قدر الإمكان على أكبر جزء من الضفة :

"إن سيطرتتا على المنطقة لا يعتمد فقط على عدد السكان ولكن أيضاً على مساحة المنطقة التي يُمارس فيها هذا الحجم السكاني بصماته وتأثيرهِ"[0] ونلاحظ مـن هذا هدفين أساسيين للسبطرة المكانيـة وهمـا الكسي والنوعي المتمتلين في تعظيم عدد اليهود المستوطنين (الموالين أيدولوجيا للفكر الصـهيوني) وبسطهم على أكبر مساحة مدكنة في مواقع استراتيجية. قد نتج عن هذا التصور وضع عدة خطط (يصعب تسميتها تتموية) يمكن تلخيص أهمها فيما يلي:

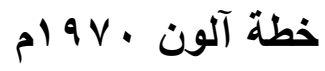

كان الهدف الأولهي لخطـة آلون إعـادة رسم حدود دولة إسـرائيل لتتضمن

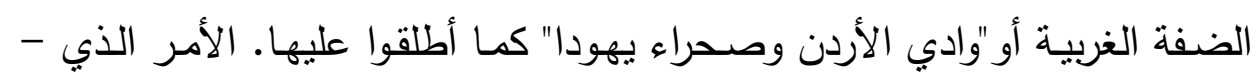
في رأيسه - كـان ضـروريا لضـمان أمسن إسـرائيل. فدعت الخطـة إلى محسور مـن ألى المستوطنات الإسرائيلية الحدودية في أقصى شرق الدولة يضمن "حضور يهودي مؤثر" ويشكّل خطوة تمهيدية لضم هذه المناطق رسميا. كما أوصت خطـة آلون

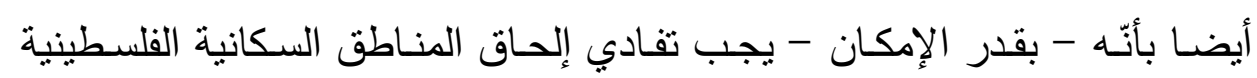
الكثيفة شكل ع.

وقد تعددت صياغات هذه الخطـة عدّة مـرات. وبـالرغم من أنها لم تعتمد

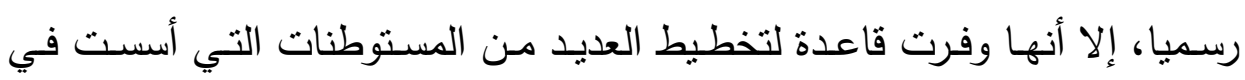

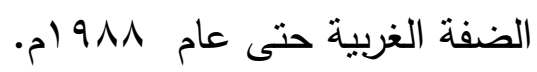



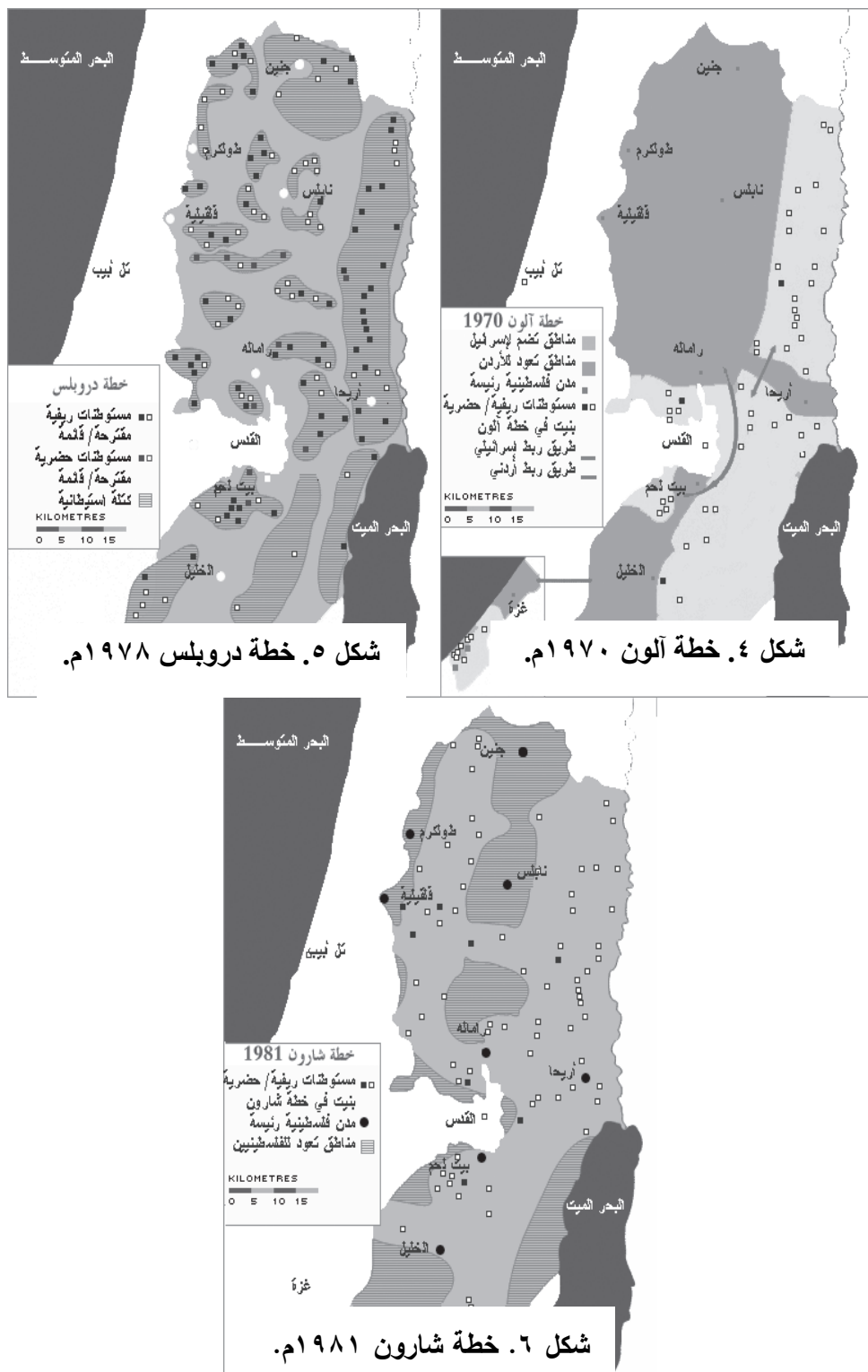

وبوصـول الليكـود إلـى السـلطة في و أم، كـان هنـاك حـوالي ثنالثين مسـتوطنة يسـكنها . . 0 ـ إسـرائيلي في الضـفة الغربيـة (ماعدا القدس الثـرقية). أغلب هذه المستوطنات أسّسـت في المنـاطق التي حددتها خطـة آلون للإلحساق بإسرائيل، والباقي اسستها "كتلة المؤمنين" خارج هذه المناطق. وقد تم تجاهل خطة 
آلون أثناء حكومـات الليكود (9VV) أخرى من الضفة الغربية. ثم عادت خطة ألون مرة أخرى لنتكّل جزء من السياسـة الرســية تحـت حكومـة الوحدة الوطنيـة برئاسـة شـمعون بيربـز وإسـحاق شـامير

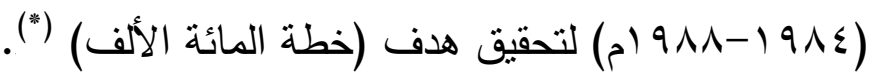

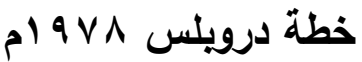

تمخض مجئ حكومسة الليكود في عام 9VV ام إلى تبني الحكومسة لخطسة جديدة للاستيطان في الضفة الغربية كان المخطط الرئيس لها "متتياهو دروبلس" رئيس شعبة المستوطنات بالمنظمـة الصـيونية العالمية. وقد تتاغمت هذه الخطة بشكل واضتح مع تطلعات حركة جوش إيمونيم من حيث الانتشار . فقد عكست هذه الخطة انحسـار المخـاوف الخارجيـة والتركيز على العامل الديموجرافي الفلسطيني ومـا يمثلـهـ مـن تهديـد للعمـق الـداخلي. فعمـدت إلـى رسـم مجموعـة مـن الكتـل الاستيطانية الإسرائيلية على أعلى قمم التلال الغربية للضفة المطلة على المدن الفلسطينية الكبرى، تهيمن عليها استراتيجيا وتطوقها. وكان الفكر السائد لها أن أي الإي غياب مكاني إسـرائيلي في مناطق النمو الفلسطيني يعني ترك فراغ حيوي لنمو الفلسطينيين يعيق السيطرة الإسرائيلية المطلقة المستقبلية لهذه المناطق شكل ه. "إنّ الحضور المدني للجاليات اليهوديـة حيوي لأمن الدولة [...] ل لا ينبغي أن يكون هنالك أدنى شكيّ بخصوص نيتتا الاحتفاظ بمنـاطق يهودا والسـامرة إلى إلى الأبد [...] وإن أفضل طريق والأكثر فاعلية لإزالة أية ذرة شكّ بخصوص هذه النية

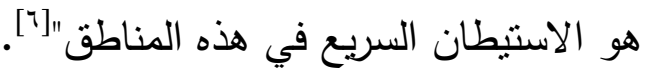

\footnotetext{
(*) خطة أعدتها وزارة الزراعة والمنظمة الصهيونية العالمية في بداية عام به ام ام عام للمستوطنات في الضفة

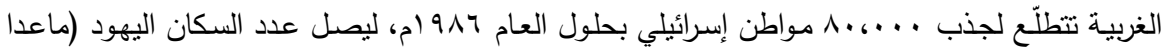




\section{خطة شارون}

كان آريـل شـارون - وزير الزراعـة آنذاك - متأثرا بتجربته الشخصية في

اختراق الدفاعات الخطية (كالثغرة في عام س 9 (م) وبالتالي كان مناقضـا لخطة آلون التي تركز على حماية الحدود بالمستوطنات. فقام بوضـع خطه حملت اسمه. وطبقا لمفهومه العسكري وخلفيته التخطيطية، يستحيل الدفاع عن خط، إذ بمجرد اختراقه من أي نقطة يصبح بـلا فائدة. ويدلل على هذا بما حدث لجميع الخطوط الدفاعية في العالم وآخرها خط بارليف. أما حله فكان يعتمد على زرع عمق الضفة الغربيـة بمستوطنات اختيرت مواقعها بعنايـة وترتبط ببعضـها البعض بشبكة من الطـرق السـربعة لتسـهل الحركـة بينهـا وبـين عمـق "إسـرائيل" (أي أرضــي عـام 19 (1) • وتمنلت المعابير في اختيار موقع المستوطنة وتشكيلها، بحيث تحنل القمـ وتطل على التجمعات السكانية الفلسطينية وتتجـة لتكثـف أي حركة على ملى الطرق من موقعها الإطلالي الكاشف ونئ.".

والمتمعن في خريطة شارون، يلاحظ أنها تأخذ شكل حرف (H). فلا يبقى سوى عدد صـير من الجيوب الفلسطينيية التي لم يعيقه عن ضمها سوى كثافة الفلسطينين بها. فمثله مثل آلون ودروبلس، من جهة السيطرة والحصار ، شكل 7. هذه الخطة والتي وإن لم تلزم الحكومة، ألزمت وزارته، وبالتالي كان لها تأثثر على أرض الواقع. وتتبع قوّة الوزارة التتفيذية من سيطرتها على إدارة الأراضي الإسرائيلية والتي تسـى "أراض الدولـة". ولذا فقد تركّزت الجهود على تأسيس المستوطنات على المنحدرات الغربية لسلسلة الجبال المركزبة للضفة الغربية. وقد عكست هذه الجهود قناعة شارون بأهمية منع خلق كيان فلسطيني متصل على جانبي الخطٌ الأخضر ، يؤدّي في نهاية المطاف إلى إتّصال منطقة غرب جنين ونابلس، وشمال

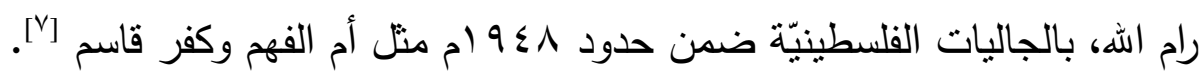


والمشترك من تحليل هذه الخطط الثلاث على اختلافها يلاحظ وضوح العزم على تحقيق ما يلي: عل

ا ـ تـأمين الجانـب الثـرقي "للدولـة" كهدف اسـتراتيجي باسـتزراع غابـات سكانية من المستعمرات اليهودية.

r. تفتيــت وعـزل وتقويض التجمعـات السـكانية الفلسـطينية بشـتى الطـرق والمسميات لوأد أي أمل في قيام كتلة عمرانية متجانسـة يمكن أن تشكل نواه دولة مستقبلية.

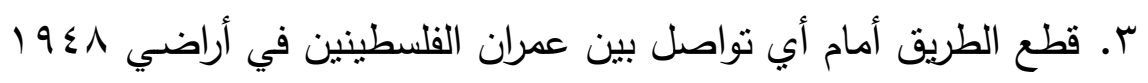
و $97 \mathrm{~V}$

؟. السيطرة على مصادر المياه.

0. السـيطرة الاقتصـادية على الفلسطينين بجعلهم توابـع مهمشـة في دورة

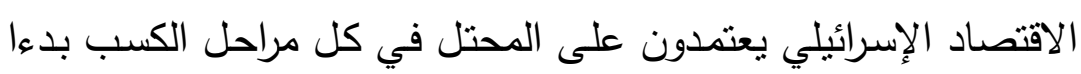
من منافذ التسويق وحتى في مجرد التصريح اليومي بتنقلهم من مقار لإن سكنه إلى مقار رزقهم. 7. - محاصرة القدس الثرقية تماما.

وفي المقابل تسعى تلك الخطط على الجانب الإسرائيلي إلى:

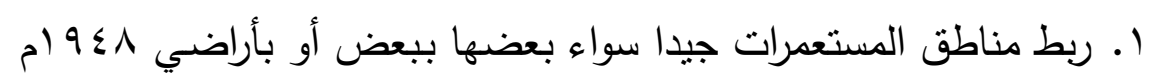
بغض النظر عن التكلفة أو الجدوى الاقتصادية. r. ضمان تواصل أكبر كتلة عمرانية استيطانية ممكنة. r. ربط المستوطنات بمقار العمالة بأقصر وأسرع وأمن شبكة طرق. ؟. محاصرة مصادر المياه والثروات الطبيعية. 


\section{ع. تلاحم التخطيط مع الأيدولوجية السياسية الإسرائيلية}

تتجلى أولى حلقات تفسير هذه الخطط من خلال ملاحظة إقحام التخطيط في عمليـة السيطرة المكانيـة في حالـة جنوب إفريقيـا. وهو مـا نـراه في تلاحم

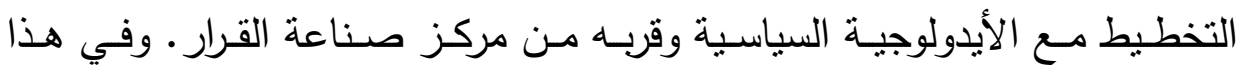

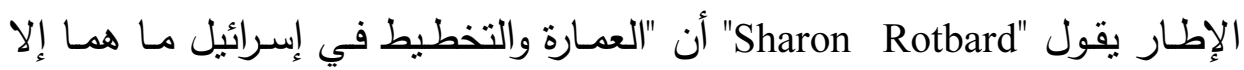

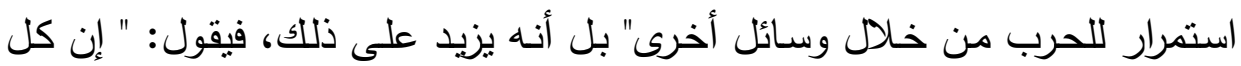

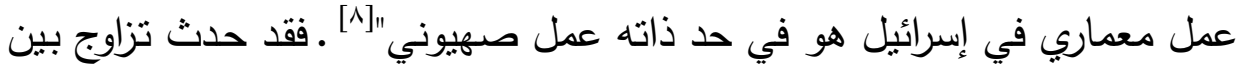

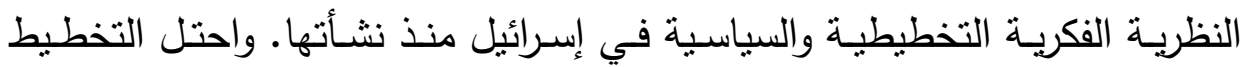

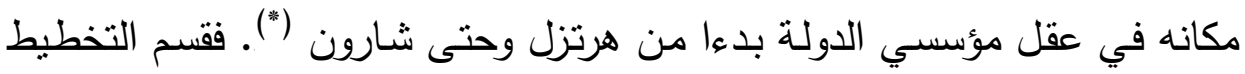

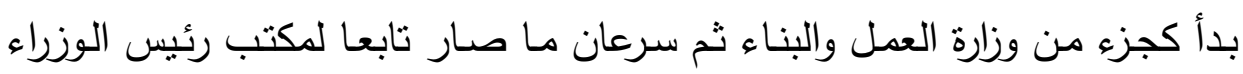

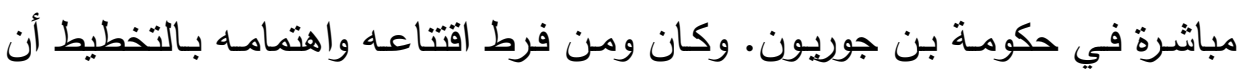

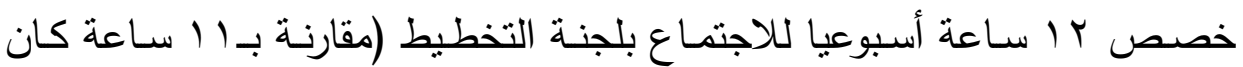

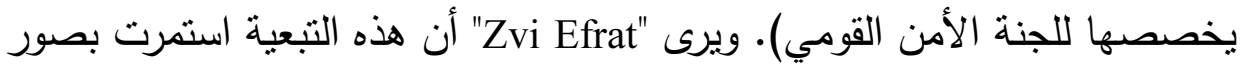

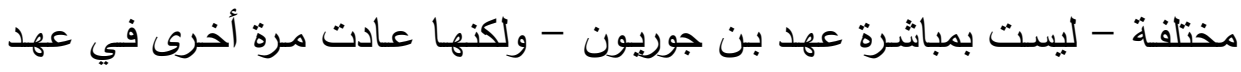

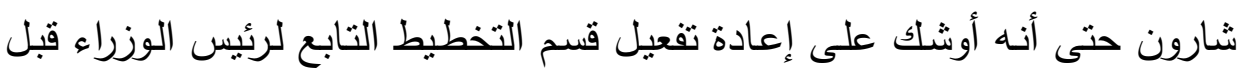

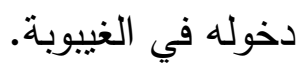

ومن المعروف أن آريل شـارون نفسـه كان مخططا عمرانيا، إذ أنه خريج

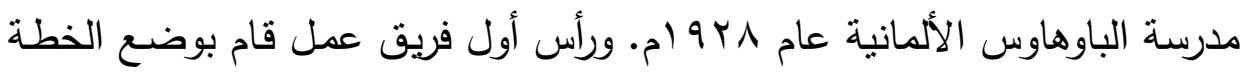

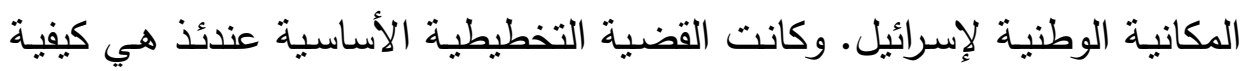

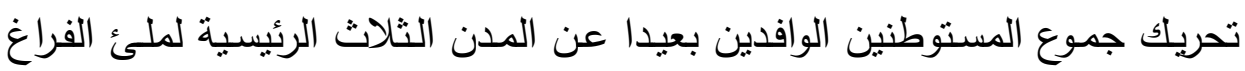

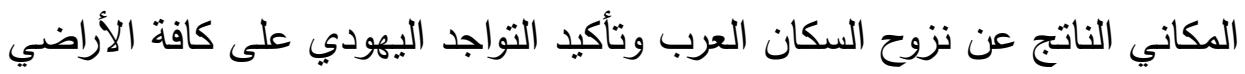

يصرح هرتزل في كتابه "الدولة العبرية" بأن "كل شئ يجب أن يعد له مقدما. وفي تفصيل الخطة يجب أن

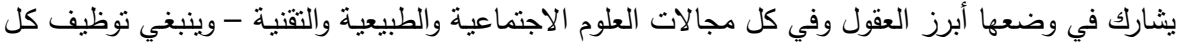
الاختراعات والتقنيات الموجودة. وحتى تلك التي لم توجد بعد. وذلك حتى يمكن احتلال الأرض وبناء الدولة". 
المحتلة حديثا. وقد تأثر شارون كثيرا بعدة أفكار منها نجاح النموذج الستاليني في روسيا مما دفعه للاقتتاع بأهمية التركيز على التتمية الريفية والتجمعات منوسطة

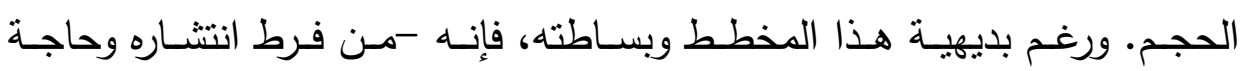
التتفيذين الإسرائيليين لأي إطار عمل - قد أصبح المسودة التي بنيت عليه معظم التنمية في إسرائيل حتى وقت قريب.

والحقيقة إن بعضـا مـن المخططين المنصـفين الإسـرائيليين قد نقد إقحسام التخطيط العمراني ودوره على خلفية أيدولوجية صهيونية. منهم على سبيل المثنال "Yiftachel" تتاقض الدور الثائع والمثالي لها من دفع عجلة التتمية مع مراعاة المساواة والعدل لـان

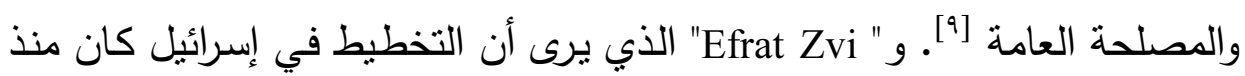
نشـأة الدولـة معدـلا تجريبيـا نتج عنهـا تشـوهات أدت إلى ظهور فكر الضـواحي المتمثل في الاستيطان في الضفة الغربية. ومنهم "Weizman"، حيث فضـح الدور الذي يلعبه التخطيط، إذ يعرض كيف تحول التخطيط إلى أداة سياسية في أيدي

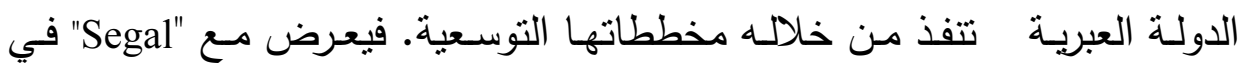

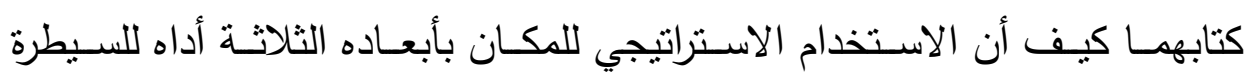

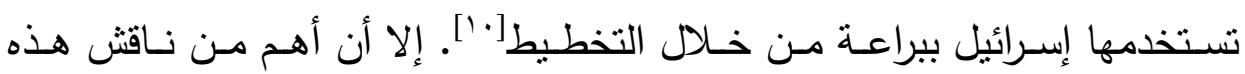

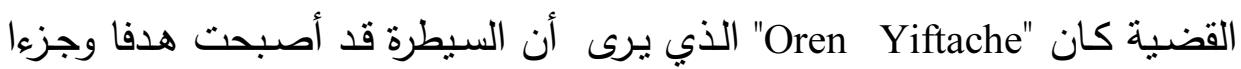

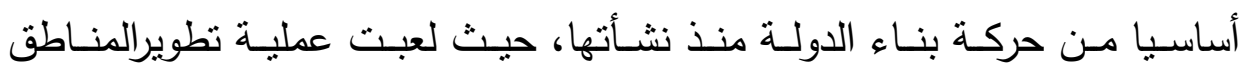

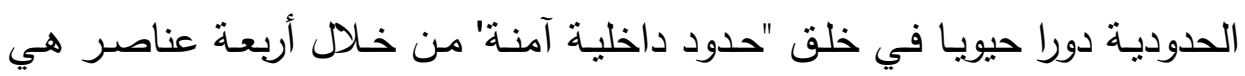
إضـعاف مصـادره الحيويـة وتحجيم نموه السكني، وتطويقه بالمستوطنات اليهوديـة والتلاعب بحدوده التخطيطية والإدارية["']

ومن هذه العناصر يمكن قراءة أهم الأهداف المرجوه من السعي لتحقيق السيطرة المكانية باستخدام التخطيط. 


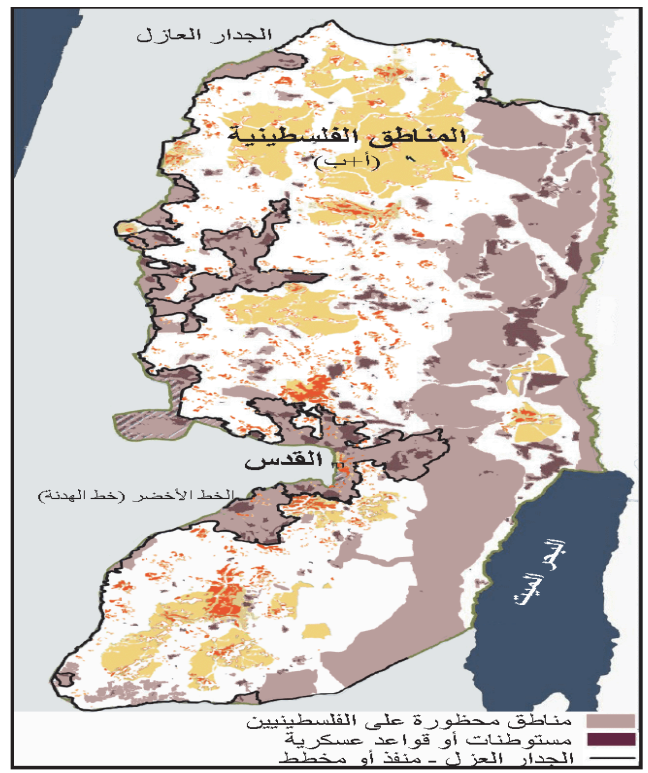

شكل V. خريطة الضفة الغربية بعد ، ع سنة من الاحتلال [r"]

\section{ع. الأدوات التخطيطية المستخدمة في الضفة الغزبية المحتبة}

قبل استعراض نلاك الأدوات بنبخي قراءة انعكاسات آخر وضع تفاوضي بين الفلسطينين والإسـرائيليين على خربطة الضفة، ألا وهو اتفاقية أوسلو المبرمسة عام ع 9 ام. رغـم أن تلك الاتفاقيـة قد تم تجاوزهـا فعليـا منذ اجتيـاح شـارون لكافة الأراضـي الفلسطينية بعد انتفاضـة الأقصىى عـام . . . بم، إلا إنها مازالت تبلور بصسورة تخطيطيـة الصـراع بين الطموحات الفلسيطينية وواقع المشـروع الصـهيوني في الضفة على الأرض. بوض.

باختصـار ، فقد قسيّمد اتفاقيـات أوسـلو الضـفة الغربيـة إلى ثلاثث منـاطق: مناطق A و B و C. وأعطيث السيّلطة الوطنية الفلسطينيّة مسؤولية الشئون المدنية (كالصحة والتعليم ورخص البناء) في المناطق A و B التي تغطي فقط اء ٪ من

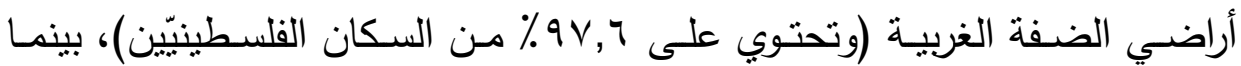
احتفظت إسرائيل بمسئولية الشئون المدنية والأمن في المنطقة C (مدا بعني فعليا 


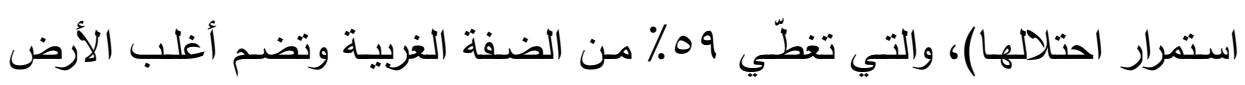

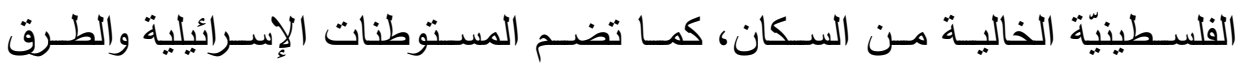

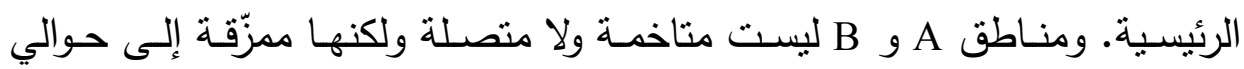

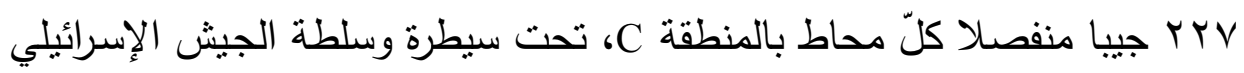
(شكل V)

ففي واقع الأمر أن الأدوات التخطيطية الإسرائيلية ما زالت مستخدمة في

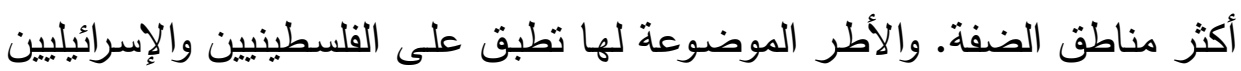

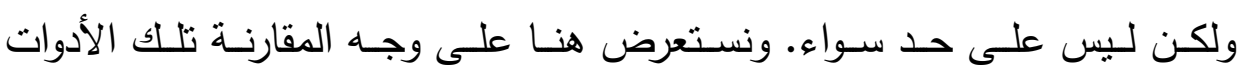

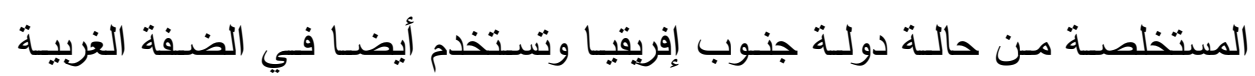
المحتلة.

1- الأدوات العمرانية

1- 1 المستقرات العمرانية الجديدة (المستوطنات)

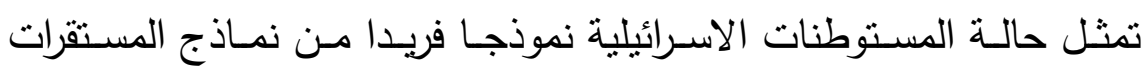

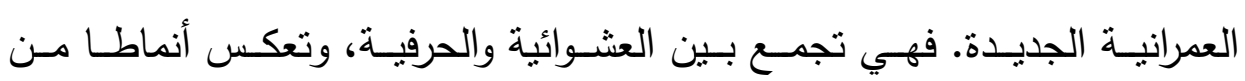

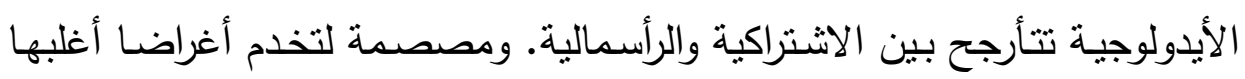

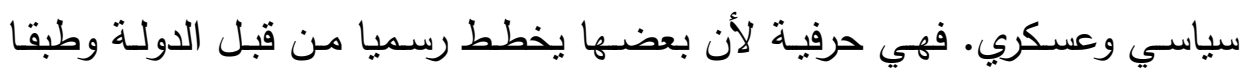
لمخططات إقليمية ومحلية محكمة ويقاول عليها أبرع المخططين اليهود. وعشوائية

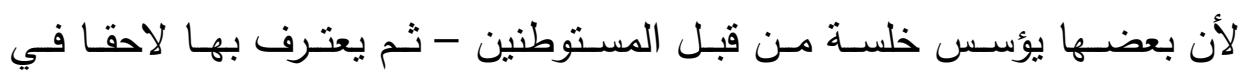

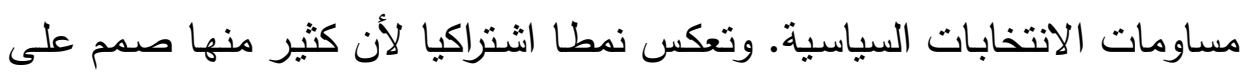

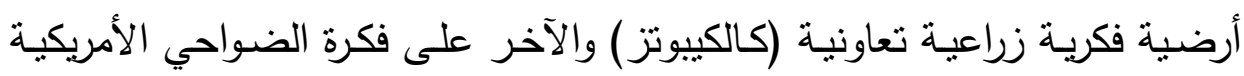

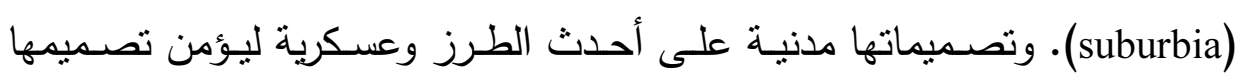

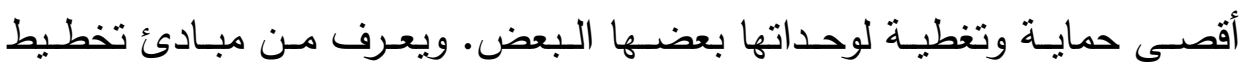

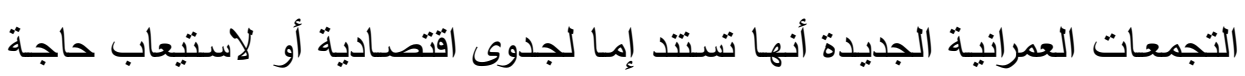

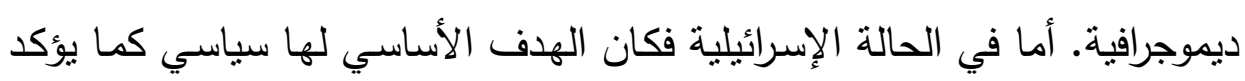




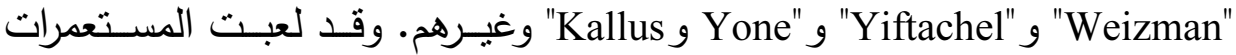

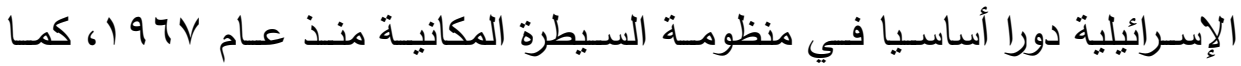

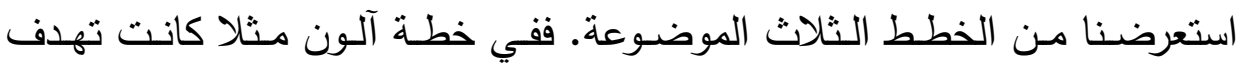
لتأمين الحدود الثرقية وبسط الوجود اليهودي على أكبر قدر من الأرض. وبزوال التهديد الخارجي، تحول التركيز على تطويق وتحجيم النمو العمراني الفلسطيني. ثم مع بزوغ مخاطر التمرد الفلسطيني الداخلي (الانتفاضات والعمليات التفجيرية)، استخدمت المستوطنات لمراقبة التجمعات الفلسطينية وكنقاط تموين وإمداد للجيش في قمع ومحاصرة واحتلال المدن الفلسطينية. وتقصيل مسألة المستوطنات يتم من خلال ثلاثة محاور وهى كمية ونوعية ومكانية.

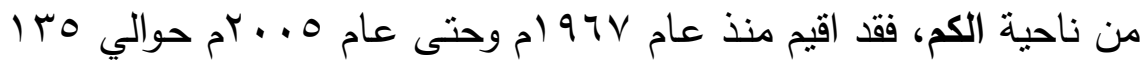
مستوطنة رسمية إسرائيلية في أراضي الضفة الغربية (بما فيها القدس الثـرقية). وتسمى "رسمية" لأن وزارة الداخلية الإسرائيلية قد صرحت بها. إلا أن هناك أكثر من مائة مدـا يطلق عليـه "البؤر الاستيطانية" والتي تعد غير رسمية. هذا على

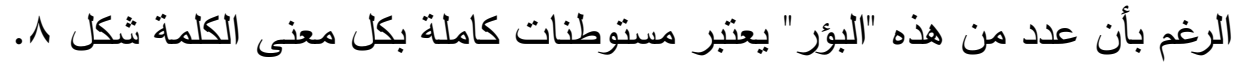
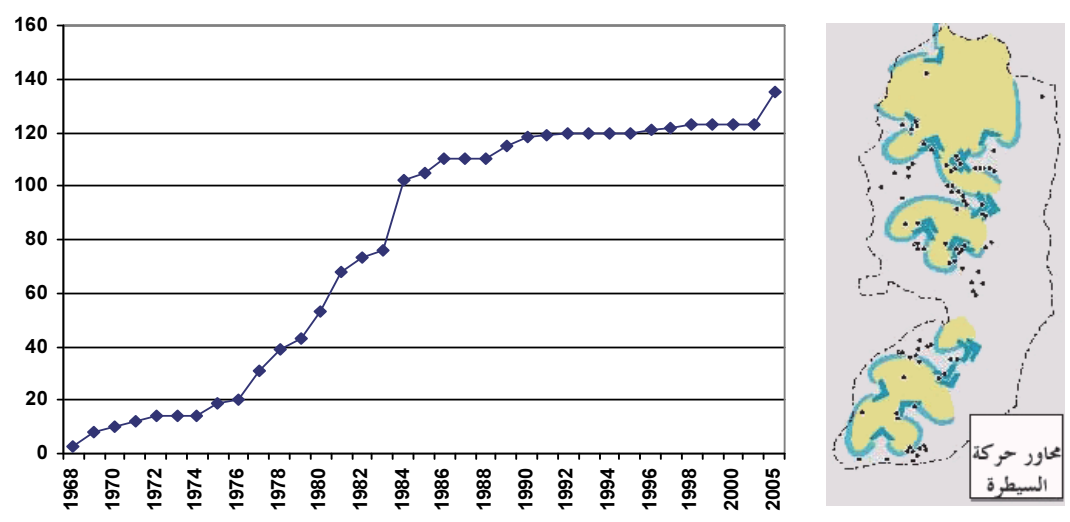

شكل ^. تطور عدد المستوطنات في الضفة الغربية منذ عام 941 احتى ه .. rام و محاور نموها. 
أما من ناحية النوع، فالمستوطنات مقسمة على أساس هيكلها الإجتماعي

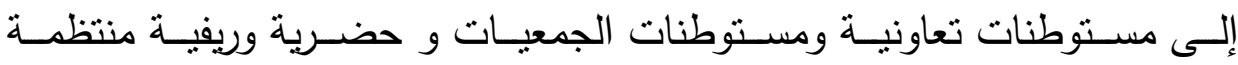

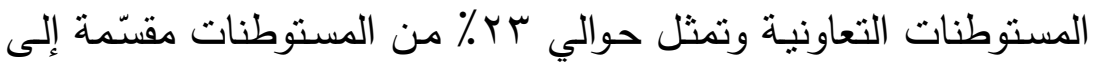

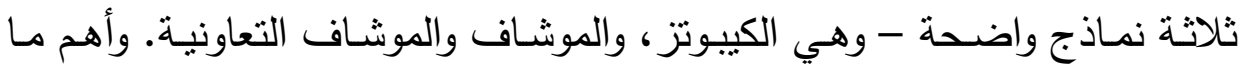

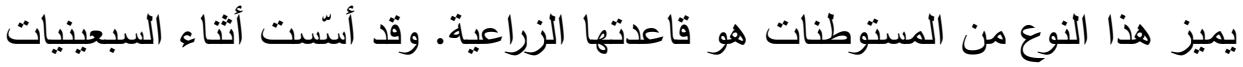

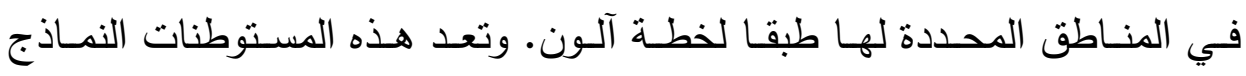
الكلاسيكية لحركة العمل الصهيونية. وعلى أية حال، فقد بهتت هذه الفروقات منذ الفات التسعينيات بسبب الأزمة الاقتصادية وتشعبّت قاعدتها لتشمل الصناعة والسياحة. • مسنوطنات الجمعيات وتمثل حوالي •0 \% من المستوطنات أغلبها في

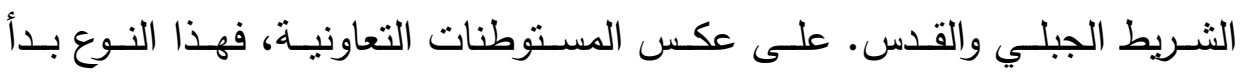
خصيصـا للمنـاطق المحتلة، وبالتحديد كمبادرة من "جماعـة المؤمنين". والإطـار

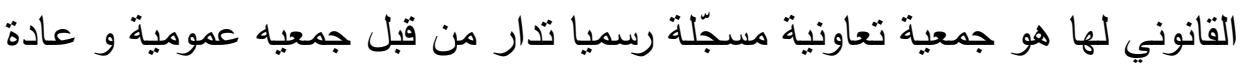

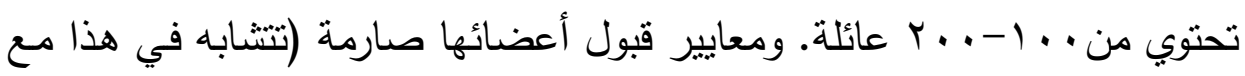

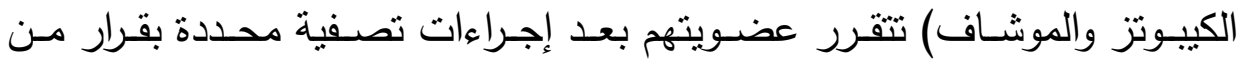

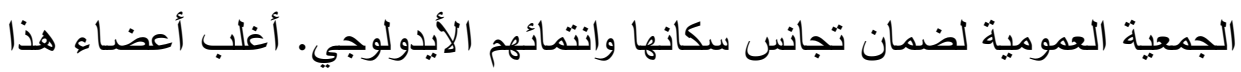
النوع من الطبقة المتوسطة من ذوي الياقات البيضاء يعملون في المدن القريبة.

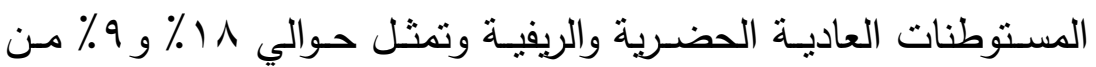

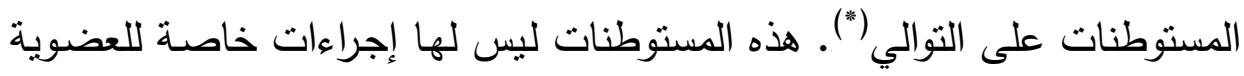

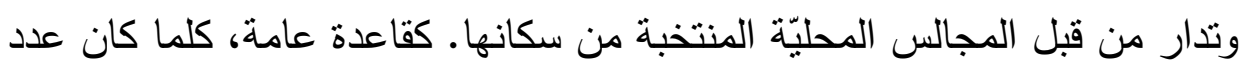

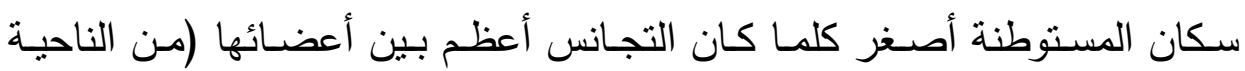
الاينية والمستوى الاقتصادي، والمنشأ).

(") يعرف المكتب المركزي للإحصائيات المستوطنة الحضرية بنلك التي يزيد عدد سكانها عن .... ب نسمة،

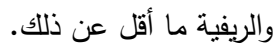


ويوضـح الثـكل 9 التالي أمثلـة مختارة لأنواع المستوطنات الإسـرائيلية في الضفة الغربية.

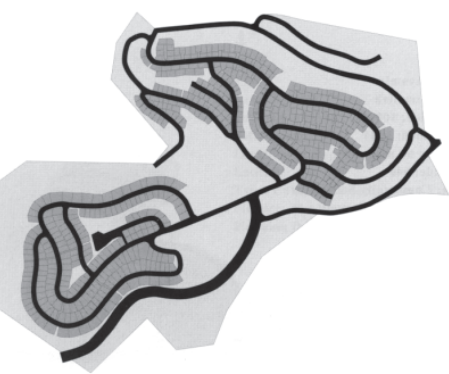

مستوطنة نآآل المنطقة: راماله

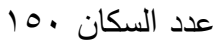
سنة الإنشاء

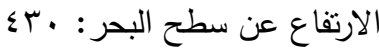

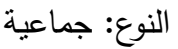
المخطط: إدارة تخطيط المستوطنات

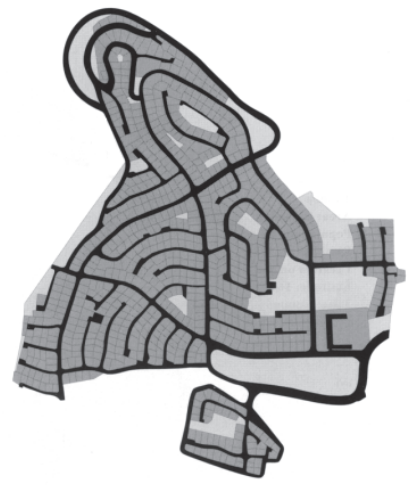

مستوطنة أورانيت المنطقة: جنين عدد السكان ... سنة الإنثاء 1910

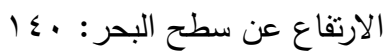

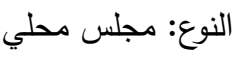

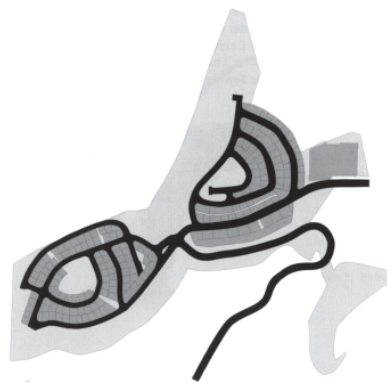

مستوطنة إيلي المنطقة: نابلس

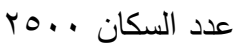

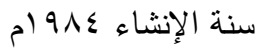

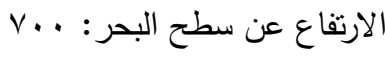

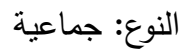
المخطط: إدارة تخطيط المستوطنات

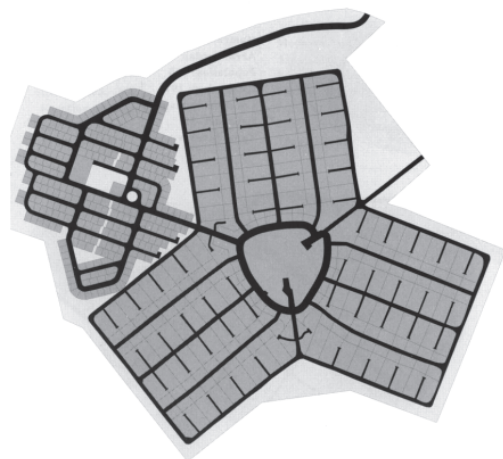

مستوطنة بتزآل المنطقة: وادي الأردن بنزآ

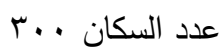
سنة الإنشاء. 197

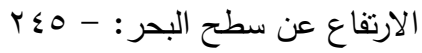
النوع: موشاف الأن اعن

شكل 9 ـ أمثلة مختارة لأنواع المستوطنات الإسرائيلية في الضفة الغربية] ·"] 
وأخيرا وليس آخرا قضية المكان. فبالرغم من تباين أنواع ومرجعيات تلك

المستوطنات، فاختيار الموقع الدقيق لكثير من تللك المستوطنات لم يكن عشوائيا

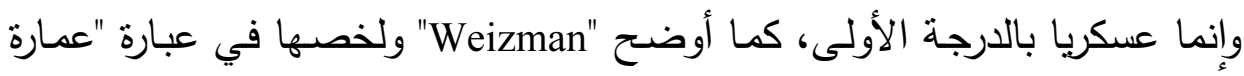

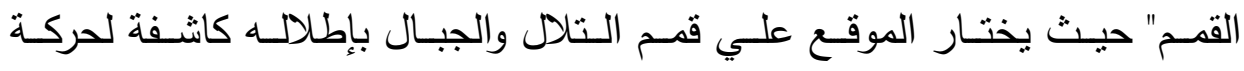
الفلسطينيين. كما اختيرت مواقعها لتحرم الفلسطينيين من مصدرين حيويين وهما الأرض والماء، خاصـة في وادي الأردن الذي يحتوي على تلك الك الموارد الحيوية.

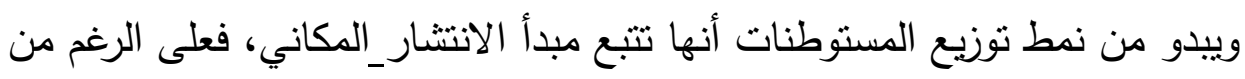

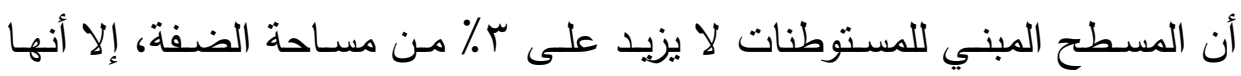

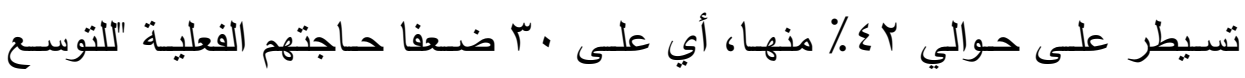

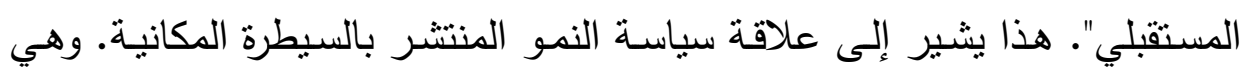

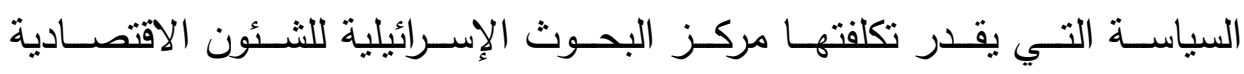

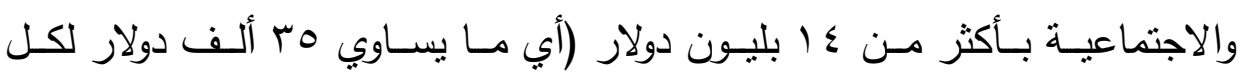
مستوطن).

\section{r- r r المخططات العمرانية}

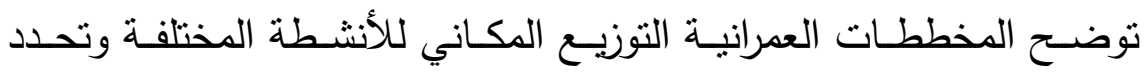

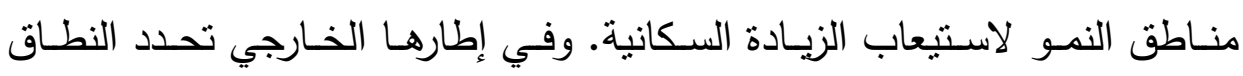

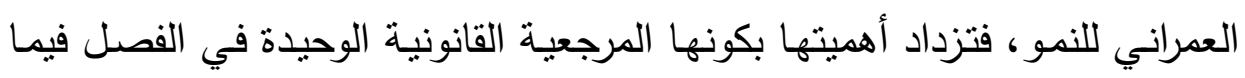

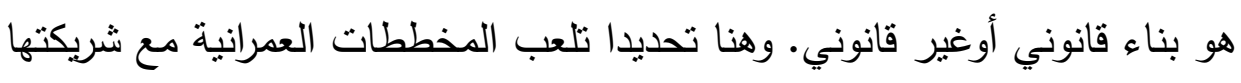

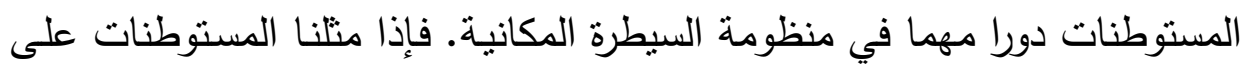

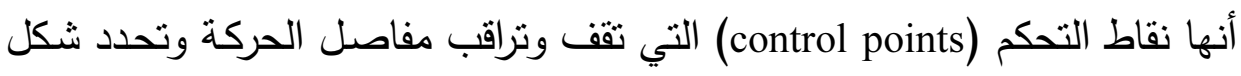
الانتشار المكاني، فالمخططات تكون بمثابة المضلعات المتروكة لتجميع السكان

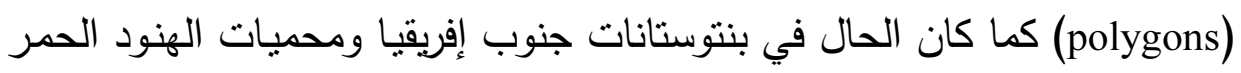

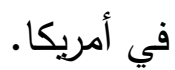


ومن المعروف أن مصداقية المخطط تتبع من حداثة متضمناته وملائمته

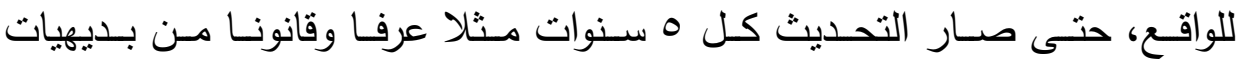

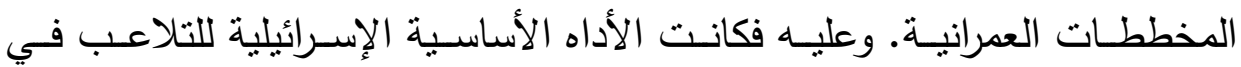
التخطيط الإقليمي (الذي هو أساس أيسة مخططات أخرى) هي ببساطة "الامتتاع عن التخطيط"! فآخر مخطط إقليمي معتمد للضفة الغربيـة وحتى تتفيذ اتفاقيات أوسلو كان هو الموضع عام • ـ9 ام! فإذا كانت المخططات الإلزامية التي رسمت وهن عام ب 9 ام للمستويات الأدنى غير مناسبة عندئذ لأنها خططت إبان الاحتلال البربطاني، فهي قطعا لم تعد صالحة اليوم. وأحد الأسباب الرئيسية لهذا هو التباين الشـديد بين حجم السكان حينها وحجمـه اليوم. فالمناطق التي كان يسمح بالبناء فيها عموما هي تلك المتاخمة للكتلة المبنية، وتلك سرعان ما نفذت. في حين أن معظم مساحة الضفة الغربية مصنفة كمناطق زراعية أو محميات طبيعية يحظر البنـاء فيها" "). أضـف إلى ذلك أن أصـغر قطعـة أرض مصـرح للبنـاء عليها هو

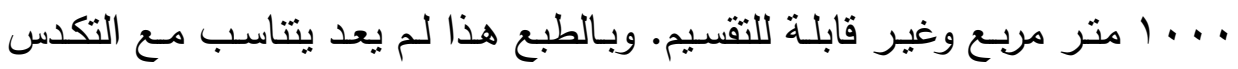
السـكاني الحـادث اليوم والمصـحوب بحظـر البنـاء خـارج الكردون. وكـان أن قـام الجهـاز المركـزي للتخطـيط الإسـرائيلي عـام ا99 ام بترسـيم الحيـز العمرانـي لأربعمائة قربة عام ا99 ام مما نزع الثرعية عن أي بناء خارجها منذ ذلك الحين وأعطى المبرر لرفض أي تصريح بناء خارجه("). و تتطبق نفس هذه القيود أيضـاء على القدس الثرقية("**".

وقد استمر هذا الوضع حتى بعد تتفيذ اتفاقية أوسلو في المناطق (ج). كما أن الحيز العمراني للكتلة المبنية

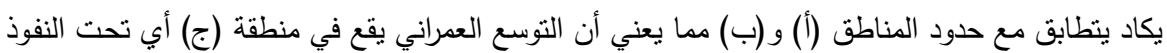

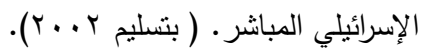

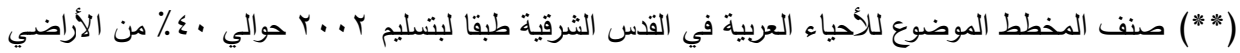

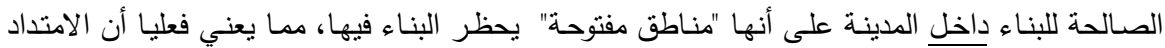
الوحيد الممكن (وليس من الضروري أن بكون مصرحا به) هو الرأسي. أو سياسة التكثيف. لأنياء 
ويوضـح جـدول ا التبـاين الثـديد فـي الكثافـة السـكانية بـين السـكان

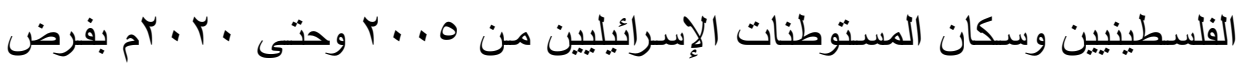
استمرار الأوضاع الراهنة.

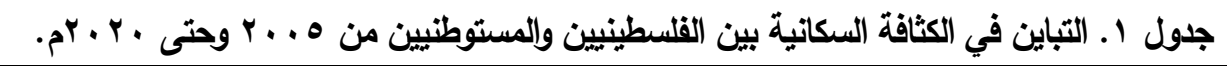

\begin{tabular}{|c|c|c|c|c|c|c|}
\hline \multicolumn{3}{|c|}{ سكان المستعمرات الإسرائيلية } & \multicolumn{3}{|c|}{ السكان القلسطينيين } & \\
\hline ش/ كَّافة & معدل النمو " " & $\begin{array}{c}\text { (بالمليون) } \\
\text { (السكان }\end{array}$ & ش/ شكثافة & النمو & (بالمليون) & السنة \\
\hline $1 \wedge 1$ & $\% 1, r$ & $\cdot, \varepsilon \Sigma$ & $9 . r$ & $\% r, r$ & r & $r \ldots o$ \\
\hline r.. & $\% 1, r$ & $\cdot, \leqslant V$ & $1.0 \mathrm{~V}$ & $\%$ \%, & $r, r \leq$ & $r \cdot 1$. \\
\hline rIT & $\% 1, r$ &., 0 . & ITKV & $\% r, q$ & $r, V \leqslant$ & $r .10$ \\
\hline TYA & $\% 1,1$ & . Or & $1 \leq \leqslant \wedge$ & $\% r, \Lambda$ & $r, Y_{1}$ & $r \cdot r$. \\
\hline
\end{tabular}

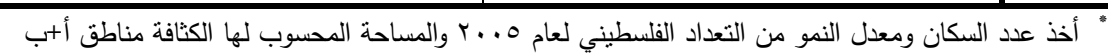
" " أخذت التقديرات المتوسطة لمعدلات النمو طبقا لمركز الإحصاء الإسرائيلي

فالواضـح أن حوالي مليوني نسمة فلسطيني (مقابل أقل من نصف مليون مستوطن) يقطنون منطقة تكاد تتساوى مع مساحة المناطق المحجوزة للإسرائيليين.

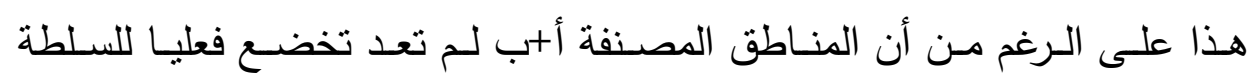

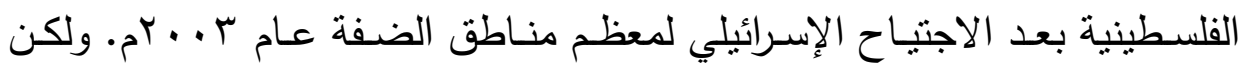
على أية حال فلو افترضنا تجميد بناء المستوطنات ومنع الهجرة إليها مع استمرار

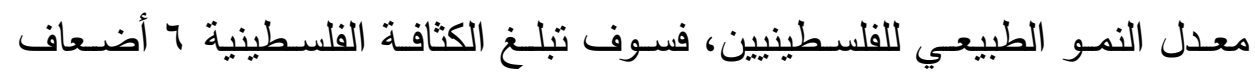

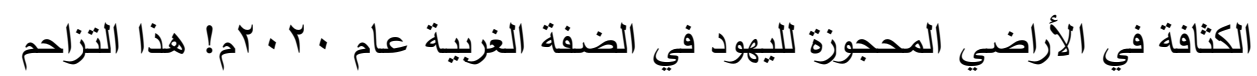
بالطبع لن يتوقف فقط عند حدود المأوى، بل سوف يعني فعليا تدهورا شديدا في

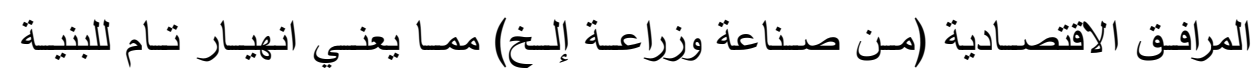
المجتمعيـة للفسلطينيين. هذا الوضـع سـوف يحدث ببسـاطة لأن الأرض المتروكة لأنة

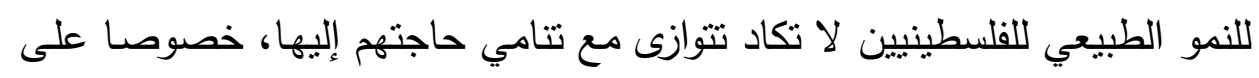
طول شربط التلّ الغربي. فحدود تلك المناطق تكاد تتماثل مع حدود الكتلة المبنية للتجمعات الفلسطينيّة. فأغلب الأرض المتوفرة للبناء على حافات القرى تقع ضمن فئن 
المنطقة (C). أي على الرغم من أن سلطة البناء والتخطيط حوّلت إلى السّلطة الوطنية الفلسطينيّة، فهو نقل لصلاحية بلا معنى.

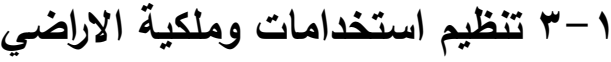

تؤثز استعمالات الأراضي على قابلية استغلال الموارد حيث تتحكم في نوع النشاط المصرح به ومن ثم درجة استغلاله واستتفاذه للموارد الطبيعية. فإذا أضفنا له بعد الملكية (من ناحية عام أو خاص)، فإنتا نصبح أمام ثنائي فعال في بسط السيطرة على المجـال الحيوي لحيـاه البثـر • وهنـا تسـتخدم تلك الأداه في إطـار السيطرة المكانيـة بحرمان الثـعب الفلسطيني من مصدرين حيويين هو في أمس وهس الحاجـة إليهمـا: الأرض والمـاء. خاصـة في وادي الأردن الذي تحتوي على تلك هلك

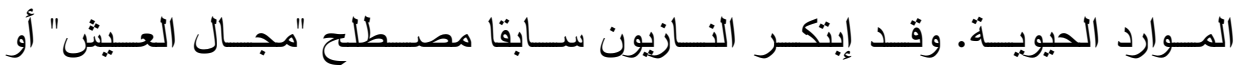
"Lebensraum" واستخدموه لتبرير احتلال مساحات شاسعة من أراضي الآخرين بحجـة اسـتخدامها مسـتقبلا في التوسـع الأفقي "لجنسـهم الراقي". وفـي الحالـة الاسرائيلية فقد اختزنت إسرائيل أجزاء كبيرة من الأراضي وحظرت استخدامها على الفلسطينيين مـن خـلال إطـارين للتحكم في اسـتخدام الأراضـي: الحدود الإداريـة والمخططات الإقليمية .

ففي الإطـار الأول، يتبـع المسـتوطنات مـا يعـرف بالحدود البلديـة وحدود

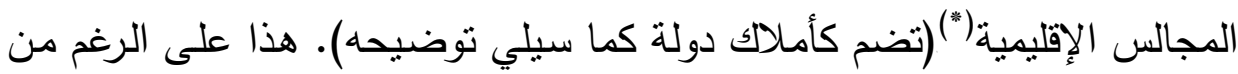
أن كثير منها حاليا يستعمله الفلسطينيون في الزراعة والرعي.

الحدود البلاية لكل مستوطنة هي منطقة نفوذ اللجنة المحلية أو المجلس المحلي (على حسب منزلة كلّ

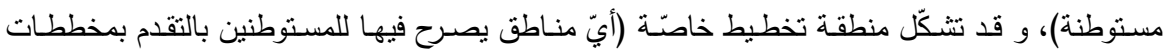

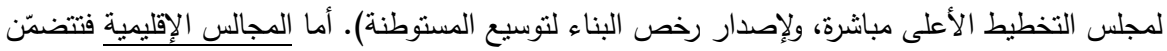

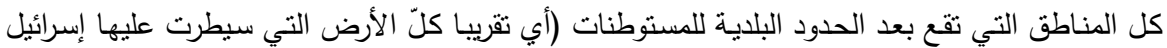

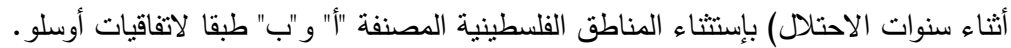


والإطار الثاني خارج تلك الحدود. فترتبط التتمية هناك بما يعرف بالمخطط الإقليمـي الإلزامسي. وهـو مخطـط لاسـتعمالات الأراضـي معـد إبـان الإحـتلال البربطاني ولم يحدث منذها. وفيه تصنف حوالي V٪ من مساحة الضفة الغربية كمحميات طبيعيـة ومنتزهات. فإذا احتاج الفلسطينيون المكدسون في مدن وقرى وفي الضفة الغربية لـأرض والموارد - رفض طلبهه طبقا لهذا المخطط. أمـا طلبـات المستوطنات للتوسـع على نفس الأرض قتقبـل، حيـث تقدم على أنهـا (تعديل)

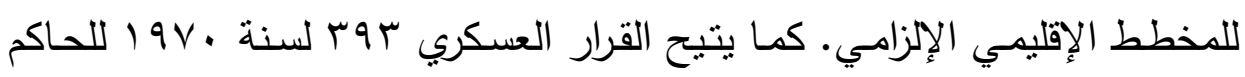
العسكري وقف البناء أو حظره في أي منطقة (للضرورة العسكرية). وعليه فتصنف العديد من الأراضـي كمناطق قتالية بدرجات متفاوته من الحظر . هذا "الجمود المرن" في نظام التخطيط العسكري يخدم المستوطنات الجديدة من دون أن يحتاج لتغيير استعمالات الاراضي ليسمح بتوسّع فلسطيني.

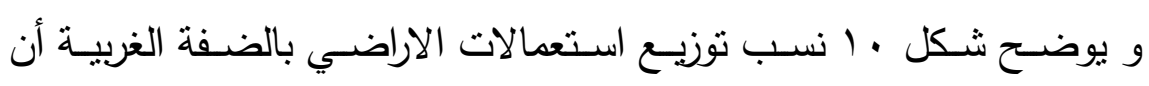

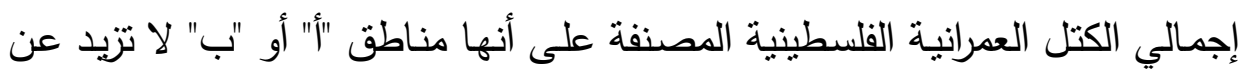

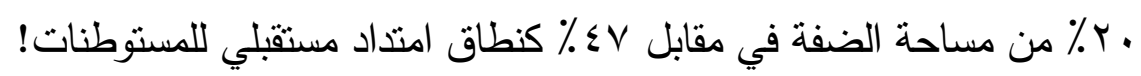

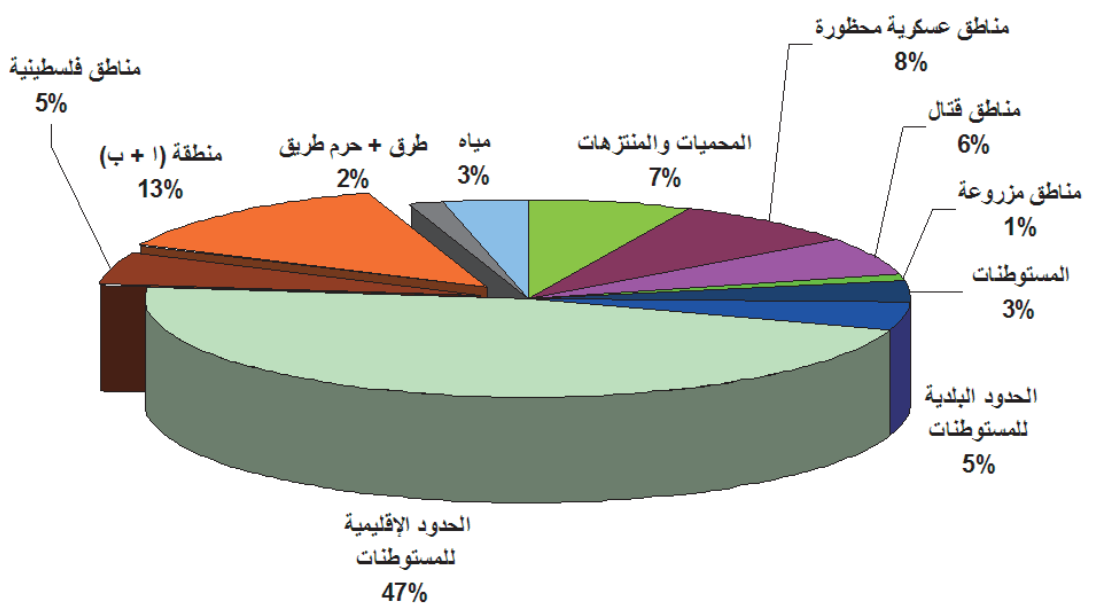

شكل ـ 1. نسب استعمالات الاراضي بالضفة الغربية.

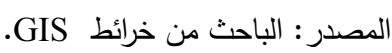


وهذا يعيد للأذهان مـا حدث في ناميييا عام \& 197 في إطـار مخطط

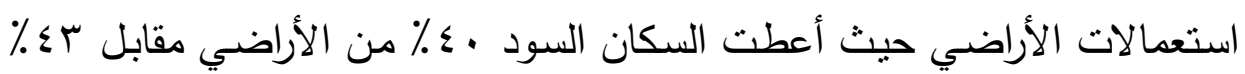

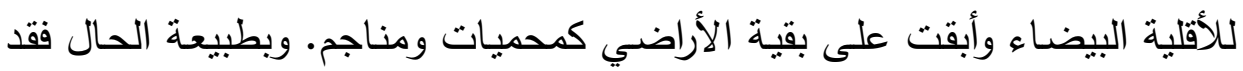

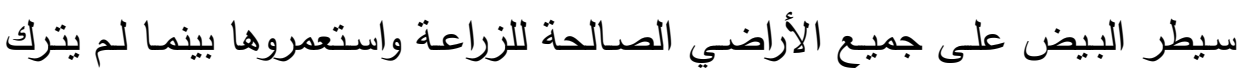

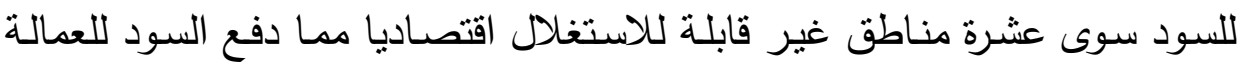

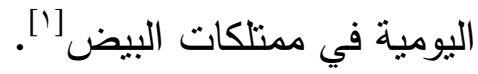

\section{1- 1 - 1 تخطيط شبكات الطرق}

تمثل الطرق الأداة الأساسية في كفاءة وفاعلية منظومـة السيطرة المكانية.

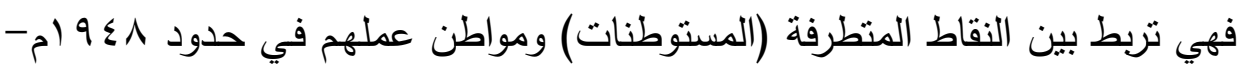

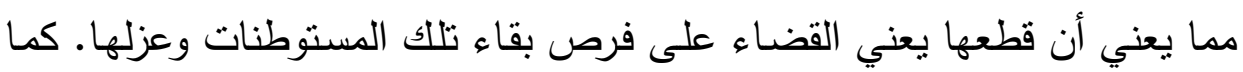

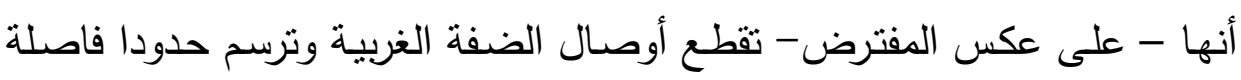

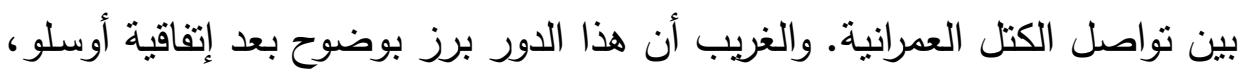

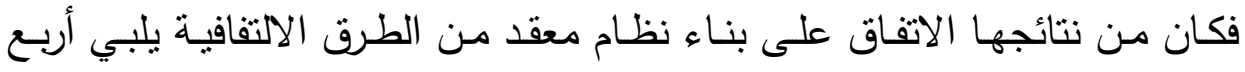
حاجات رئيسية لوزارة الدفاع الإسرائيلية("):

( ) للسماح للإسرائيليين بالسفر بدون اختراق المراكز السكانية الفلسطينيّة. r) للسماح للإسرائيليين بالسفر عبر الخط الأخضر بأقصر الطرق. ؟) الإبقاء على "نسيج داخلي من الحياة" لكتل المسنوطنة الإسرائيلية. ع) ضمان عدم المرور الفلسطينيّ للمستوطنات.

وعليه فقد ابتكر الاحتلال ثلاثة أنماط من الطرق في الضفة الغربية لفرض

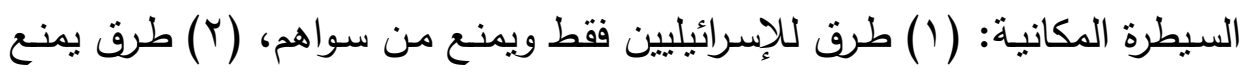
فيها مرور الفلسطينيين إلا بتصريح خاص، (r) طرق يصرح للفلسطينيين بشكل مقيد بدون تصريح خاص. 
وكـان مـن نتيجـة ذلك أن أصـبح الفلسطينيون يدورون في الرحسى لبلوغ غايتهم، مارين بالعشرات من نقاط التقتيش الثابتة والمتحركة ومعرضون للإهانه

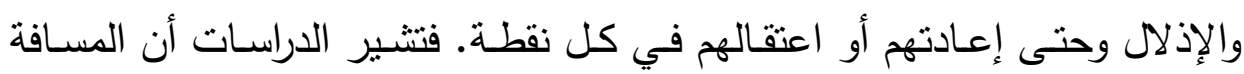

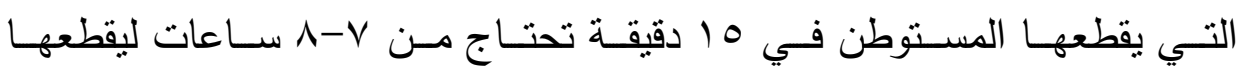
الفلسطيني. و قد أصبحت بالفعل الضفة الغربية مقطعة الأوصال ويوضح الثنس الثكل

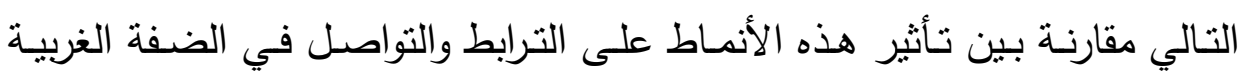
(شكل (1) (1). (ن)

\section{(Edges) - 1 الحدود العمرانية}

يعد الجدار الفاصل بالضفة الغربية مثالا صارخا على نوظيف فكرة الحدود

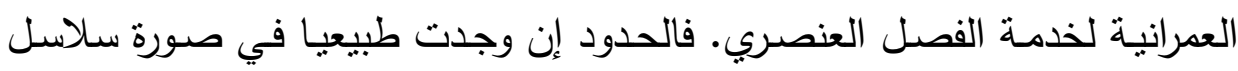

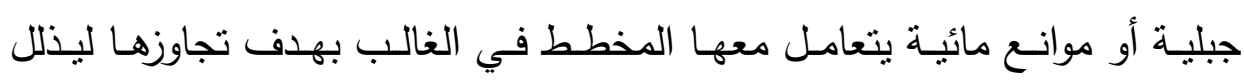

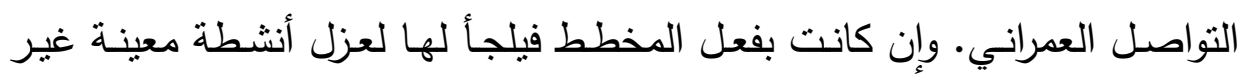

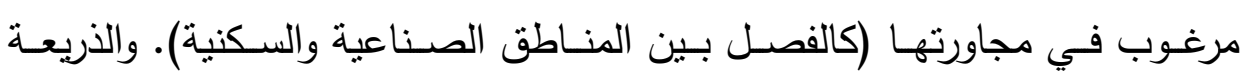

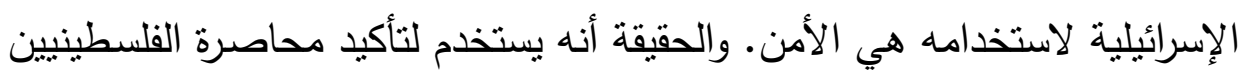

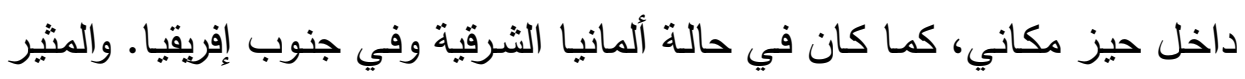
أن شارون كان من غير المقتتعين بجدواه ويراه حلا فانشلا تاريخيا.

ويرجع تاريخ الجدار لثـهر يونيو r . . بم عندما قررت حكومـة "اسرائيل" اقامة جدار فاصل بهدف منع دخول الفلسطينيين إلى "اسرائيل" دون رقابة. ويتكون

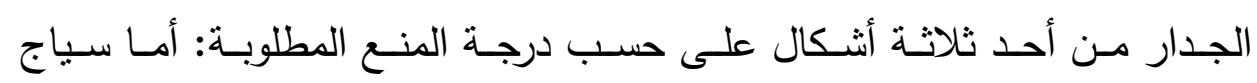

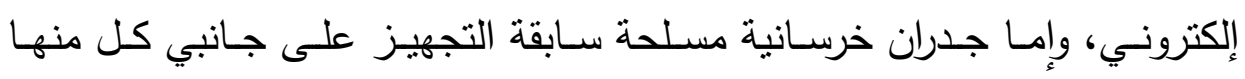

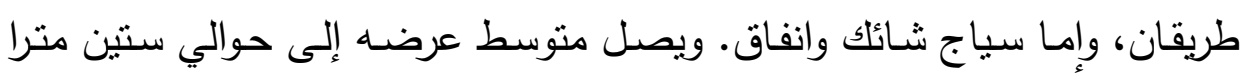
(شكل r I ). 

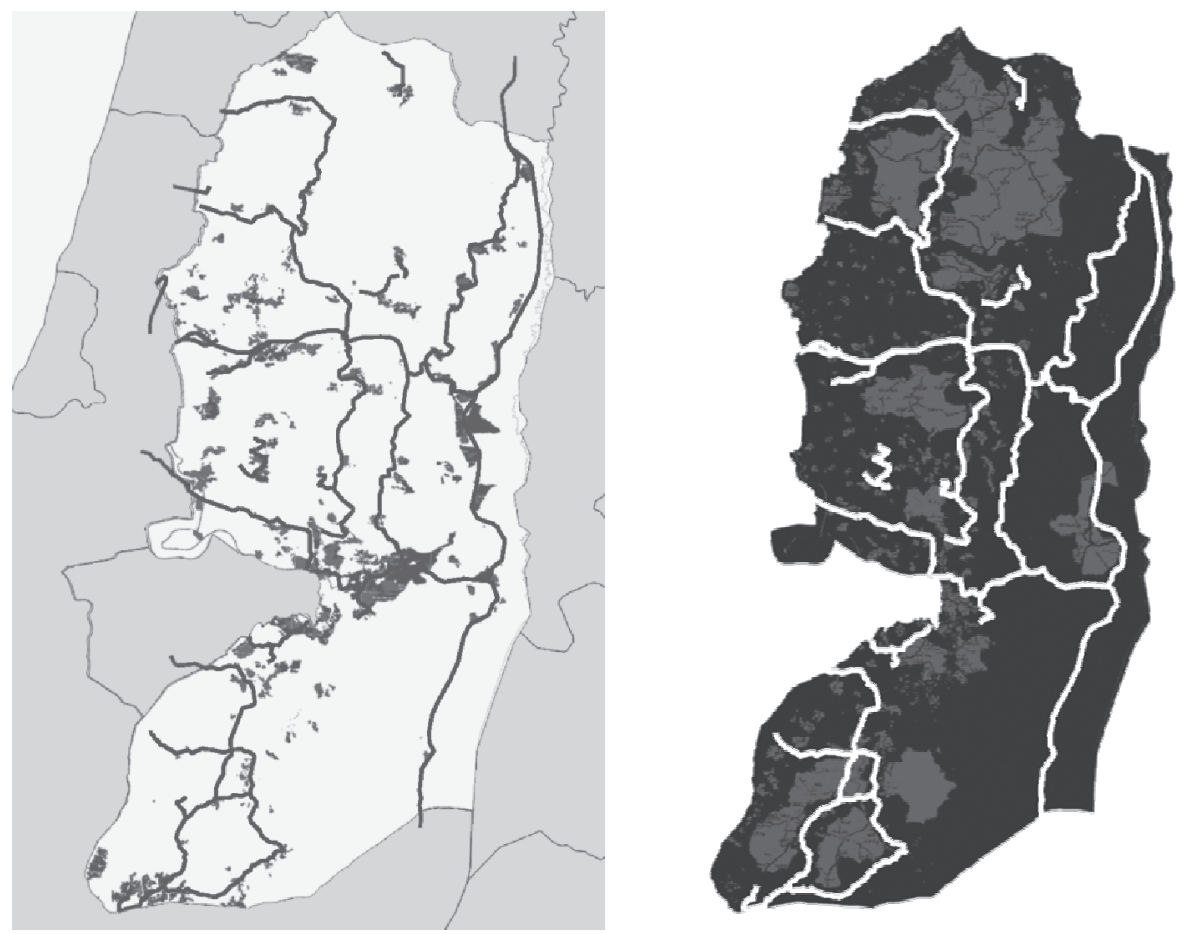

شكل 11. الطرق الالتفافية تحاصر وتعزل المناطق الفلسطينية (يمين) الطرق الإلتفافية تريط وتوصل المستوطنات (يسار).
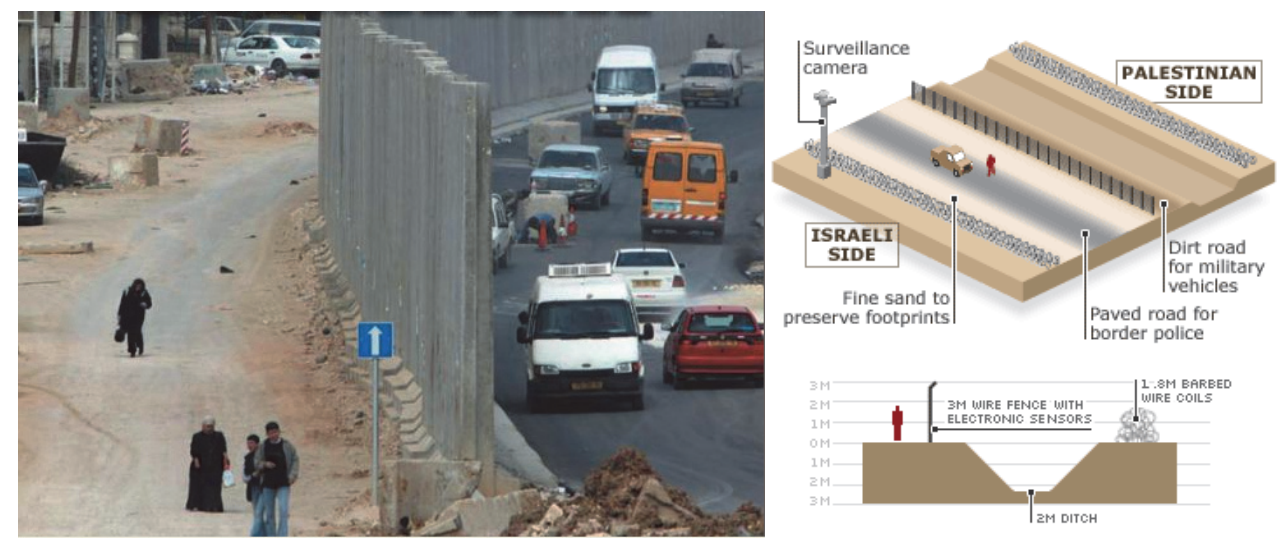

شكل r ا . تصميم الجدار العازل و صورة توضح جانبية. 
وقد مر مسار الجدار المخطط بعدة تعديلات بقرارات من المحكمة العليا الإسرائيلية أو نتيجية لضغوط سياسية أمريكية أو من المستوطنين. وتنشير العديد

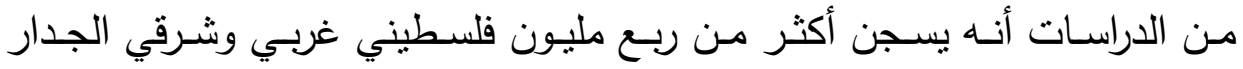

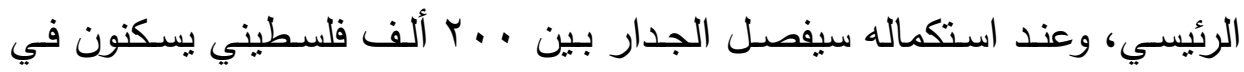

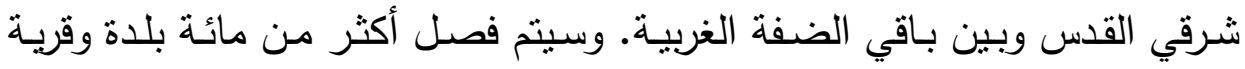

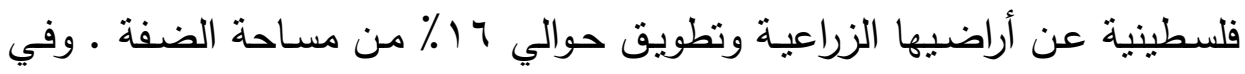

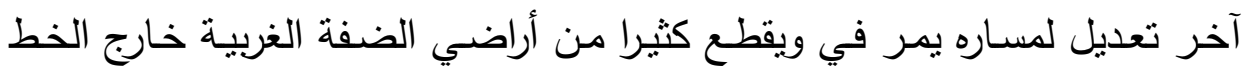

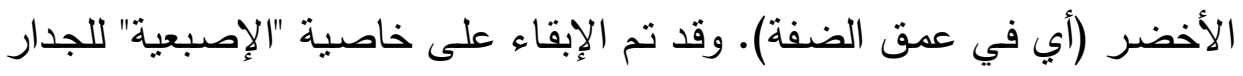

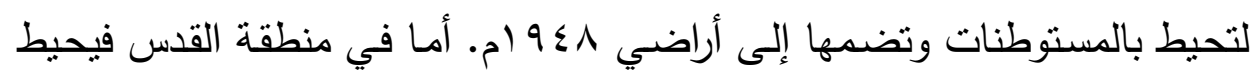
الجدار الفاصل شرقي القس ويفصلها عن باقي أراضي الضفة الغراضي الغربية.

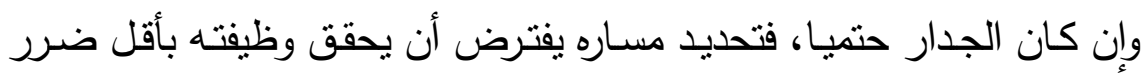

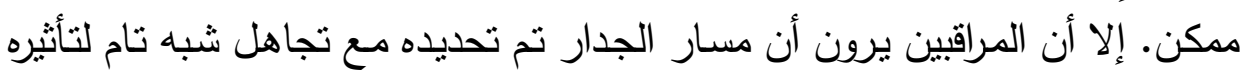

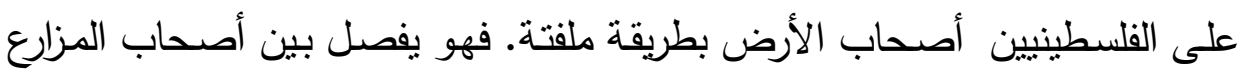

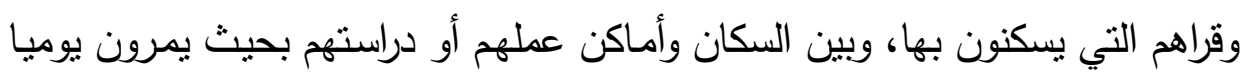

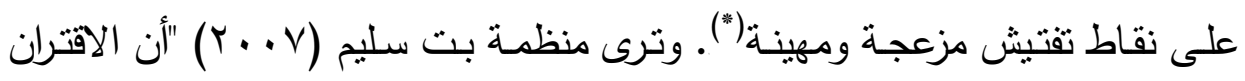

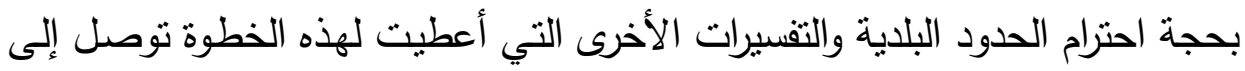

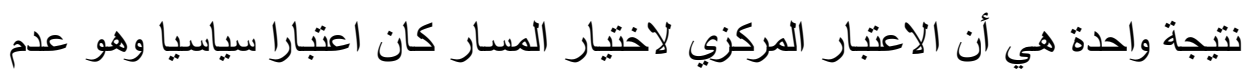

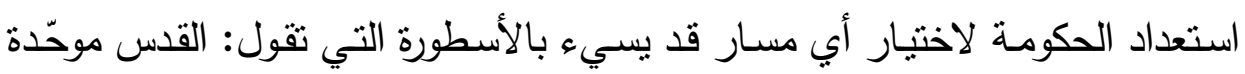

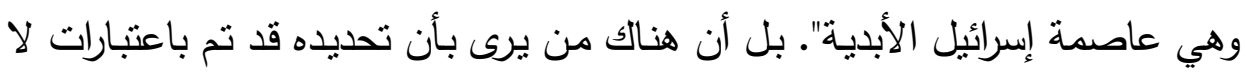

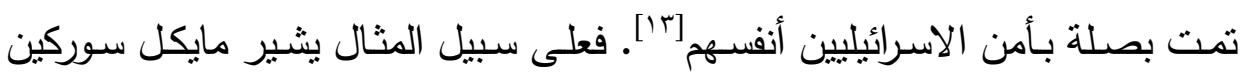

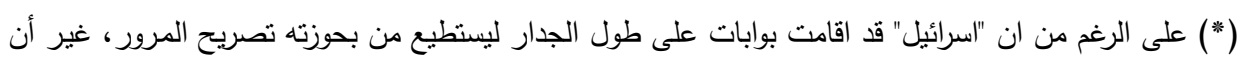

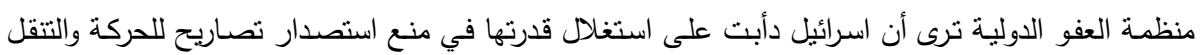

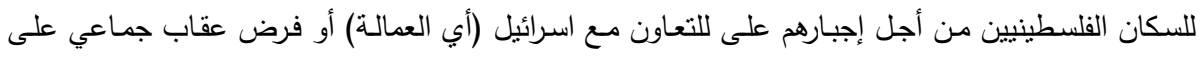

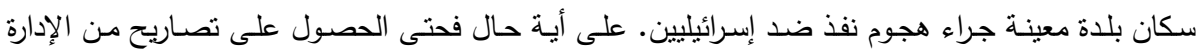

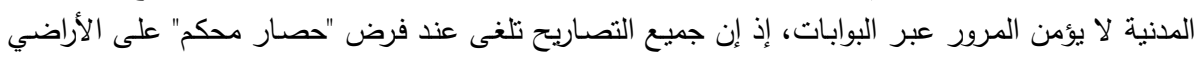




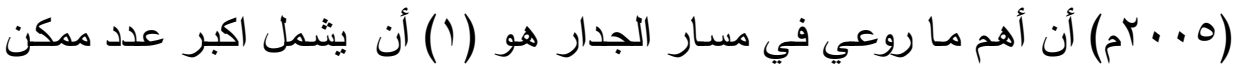

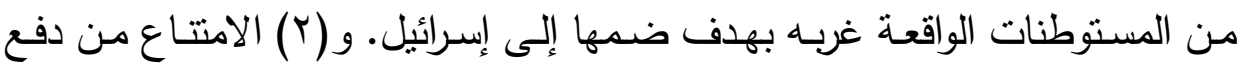
الثمن السياسي الذي ينطوي عليه الاعتراف بالخط الأخضر كخط لحدود إسرائيل [ـ "] أمسا عن علاقة الجدار بمنظومـة السبطرة المكانيـة فهي معقدة بعض الثـئ.

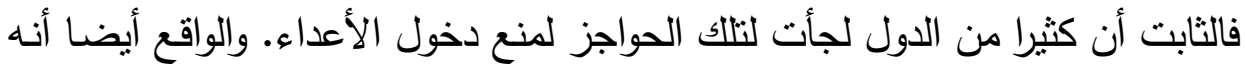

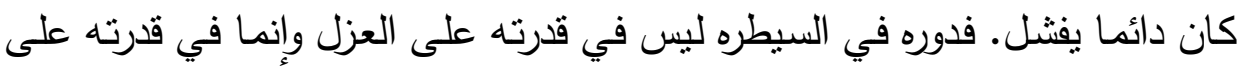

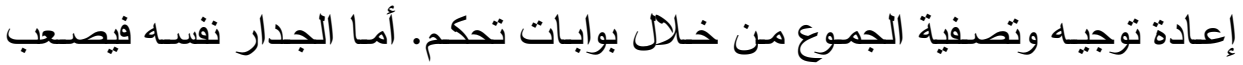

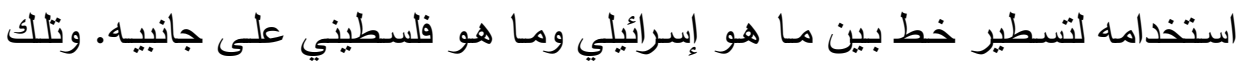

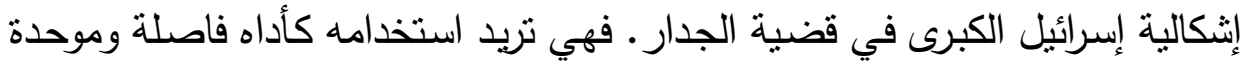
في آن واحد. فتريده أن يفصل بين السكان غير المرغوب فيهم ومواطنيها في نفس

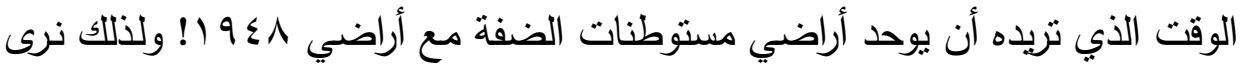

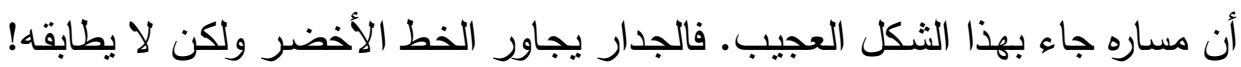
وهو يضم العديد من المستوطنات وليس كلها!

\section{r) ( الأدوات التشريعية والمؤسسية}

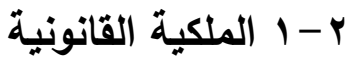

لا شك أن من أدوات السيطرة المكانبة على الأرض هو ببساطة: امتلاكها!

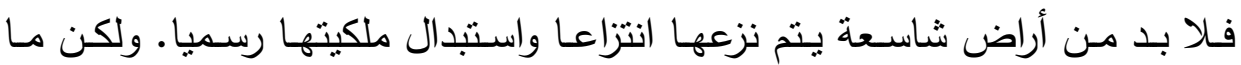
السبيل إلى ذلك والضفة الغربية محتلة وسكانها موجودون؟

تفتق ذهن المحتل عن عدة صيخ تخطيطية قانونية تتيح له تتفيذ مخططاته.

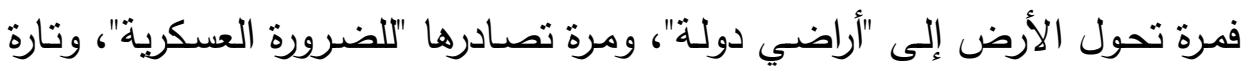
تعتبرها "ملكية متروكة"، وأخرى تتزع للمنفعة العامة. فعلى سبيل المثال، تم توفير

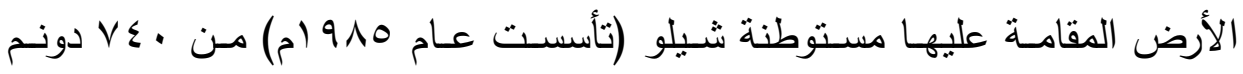
استولت عليها إسرائيل للضرورة العسكرية، و ـ10 دونم أراضي رسمية، و إك دونم

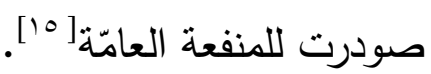


ولكي تلقي ظلالا قانونية لمشروعها، طبقت إسرائيل القانون الأردني بذريعة

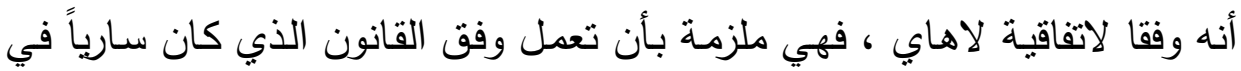

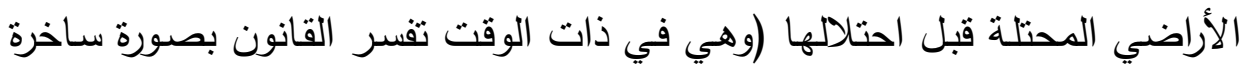

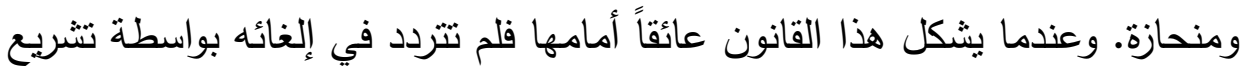

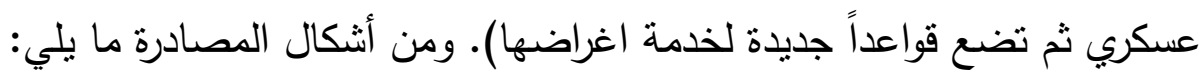

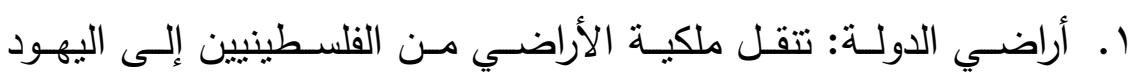

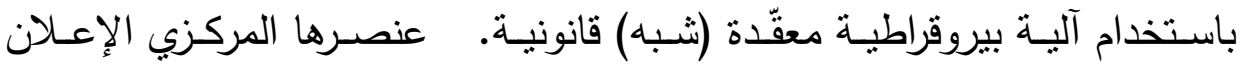

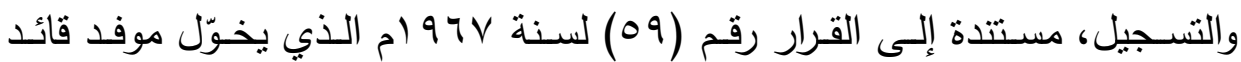

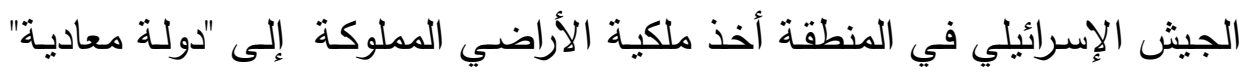

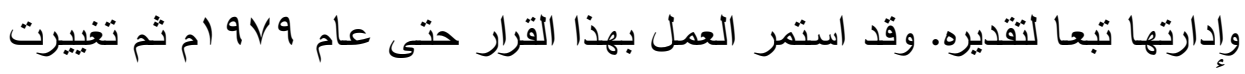

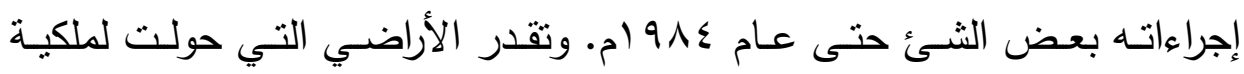

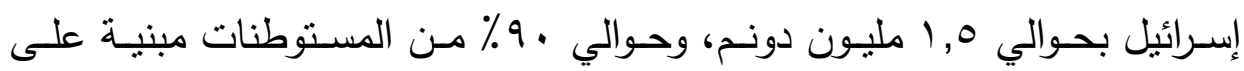
أراضي من هذا النوع.

r. مصـادرة الأرض للضرورة العسكرية: رغم وجوب الحفاظ على الملكية

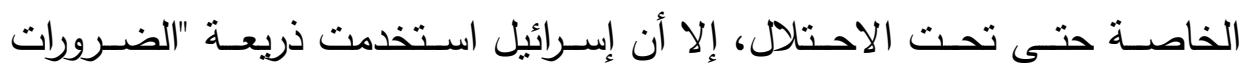

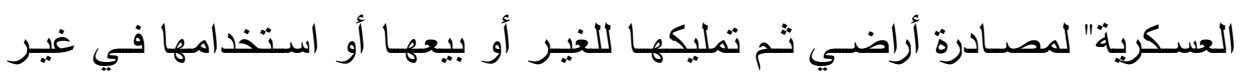

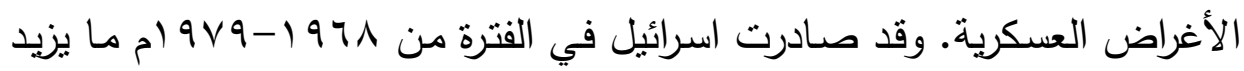

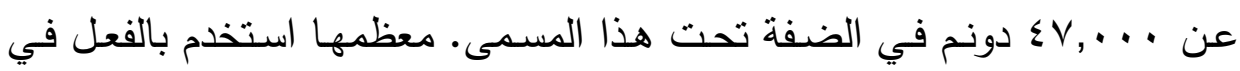

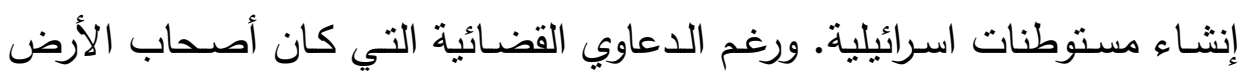

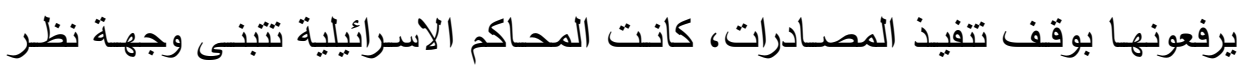

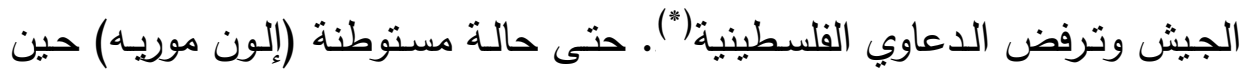

(") بلغ من غرابة تفسيرات القضاه أن أحدهم صرح بأنه حتى وإن كان سكان المستوطنات لا يعطون بالجيش، إلا

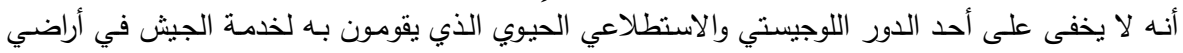
"العدو". كما أنه لم يجد تتاقضا بين إدعاء أن المصادرة مؤقته وبين أنها كاملة المرافق! (Bet El,p. 119).

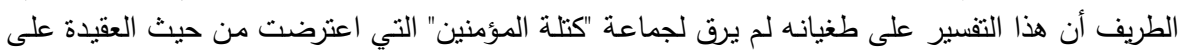
التبرير العسكري لوجود المستوطنات الذي يوحي بأن الأراضي محتلة؛ لئل 
طالب الفلسطينيون بوقف المصسادرة وقدموا أدلـة دامغـة للمحكمة العليـا كان مـن ضمنها شهادة رئيس الأركان الأسبق الذي قرر أن إنشاء هذه المستوطنة لا يخدم

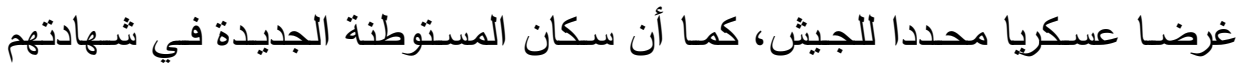
للمحكمة رفضـوا فرضية أن تكون المستوطنة مؤقتـة أو أنها مقامسة لتخدم غرضـا

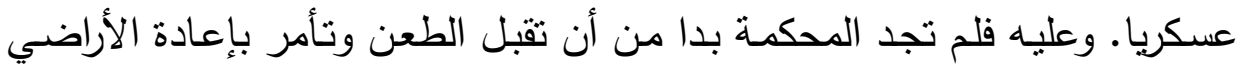
المصادرة. وكان من نتائج هذا الحكم أن نتبه الجيش ولم يعد يستخدم هذا المبرر في استيلائه على الأراضي الفلسطينية من عام 9 أم وحتى ونى توقيع اتفاقية أوسلو

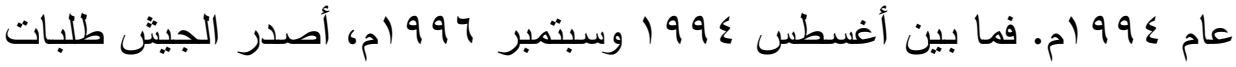

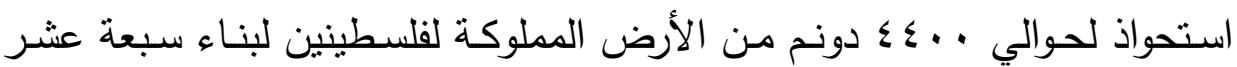
طريق طريق التفافي. ورغم الدعاوي القضائية التي كان أصحاب الأرض يرفعونها بوقف تتفيذ المصـادرات لدعواهم بأن بناء الطرق الموصلة للمستوطنات لا يمكن

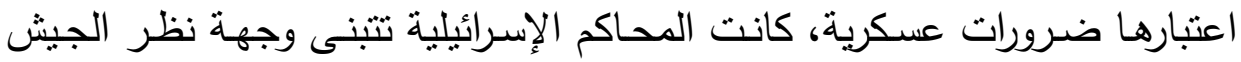
وترفض الدعاوي الفلسطينية.

r. الملكية المتروكة: طبقا لهذا القانون، فأي أرض تركها مالكها أثناء أو بعد حرب 97 ام تعرف كملكية منروكة وتؤول إلى إدارة الوصاية على الأراضي المنروكة نيابة عن القائد العسكري في المنطقة. وللوصي الحق في أخذها وإدارتها كما يحلو له- حتى وإن كان صاحب الأرض معروفا ومسجلا. ثم توسّع التعريف ليتضمن المقيمين في بـلاد العدو. وقانونا فالوصي يدير الأرض نيابة عن المالك

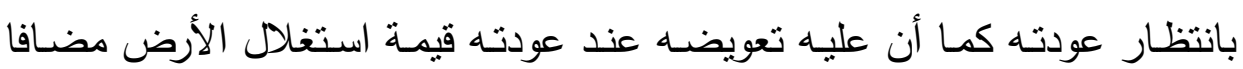
عليها قيمة التضخم. ولكن في الواقع قلما حدث ذلك.

ـ. نـزع الملكيـة للمنفعـة العامـة: تتزع ملكيـة الأراضـي في الضـفة الغربيـة تحت بنود قانون أردني يحدّد الاستخدامات والجهات المعنية بنزع الملكية. ويصرّح القانون الأردني بشكل محدّد بأنّ نزع ملكية الأرض مسموح به فقط لغرض المنفعة العامّة. لذا فلم تستعمله إسرائيل على نطاق واسع لبناء المستوطنات، باستثناء حالة 


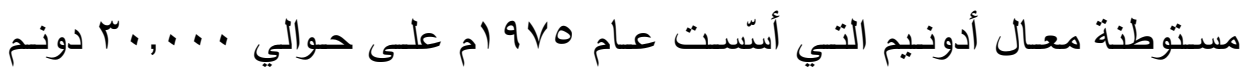
صـادرتها من الفلسطينيين. ولكن إسرائيل إستعملت هذا القانون على نطاق واسـع لبناء شبكة متكاملة من الطرق تخدم المستوطنات، توصل المستوطنات بعضـها بـالبعض وبإسـرائيل، متجنبـة فـي أكثر الحـالات المـرور مـن خــلال أو خدمـة التجمعات الفلسطينيّة.

\section{r r r أظام للتخطيط العمراني}

إنّ أهمية أيّ نظام تخطيطي هو أنه يهتم بتحديد إستعمال الأرض المتوفره للجمهور طبقا لاحتياجاته وتصـورّاته ومصـالحه (ككل، ولأفراد الذين يثكلونه). والوثيقة التي تفصّل هذه القرارات هي المخطط العام (outline plan) الذي يقرّر نوع ومساحة وموقع وتقسيم كلّ وحدة أرض (إسكان، وصناعة، وتجارة، ومؤسسات عامّة، وطرق، ومنطقة مفتوحة ومـا شـابه). ويمنثل نظـام التخطبط الإطـار العـام للعمليـة التخطيطيـة حيـث يقوم بتوزيـع الأدوار المختلفـة على المعنيـين بالعمليـة

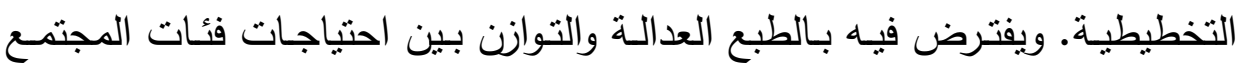
المختلفة ومشاركتهم. أما في حالة الاحتلال، فمثله مثل سائر الآليات المطبقة في

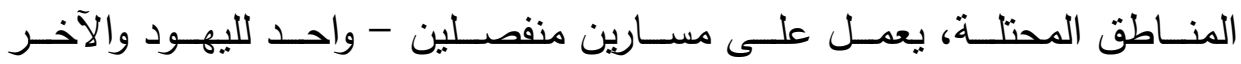
للفلسـينيين. فبينمـا بعدل النظـام بشـدة لتأسيس وتوسيع المسـتوطنات، يتصـرّف أيضا بجدّ لمنع توسّع من البلدات والقرى الفلسطينيّة ليظهر التناقض بين مصالح

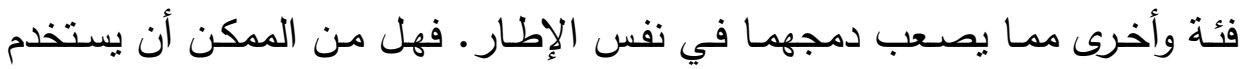
المخطط نفس النظام لغرضين متتاقضين؟

نظرا لوضعية الضفة تحت الإدراة الأردنية قبل احتلال عام 97 (م، فيطبق القانون الأردني رقم V9 لسنة 979 ام الذي يقسم التخطيط إلى ثلاثة مستويات (إقليمي وعام وتفصيلي، بنفس الترتيب متدرجا من الأعلى للأدنى). ومن المفترض الته

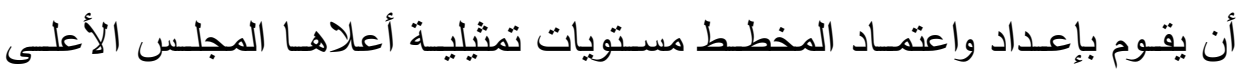


للتخطيط ولجنة لتخطيط المنطقة ولجنة التخطيط المحلية. وتمثل مجالس الوحدات المحلية للقرى والمدن جهات اعتماد المخططات.

لكن المحتل أدخل عدة تغيرات على هذا الإطار على مدار السنوات أفقدت الفلسـينيين أيـة سـلطة فعليـة. ففي عـام 9 ام صـدر قـرار الحـاكم العسكري الإسرائيلي رقم 1 اء بنقل جميع صـلاحيات القانون من وزير الداخلية إلى الحاكم العسكري للضفة. ثم تم استبدال جميع الموظفين الأردنيين والفلسطينيين في اللجان

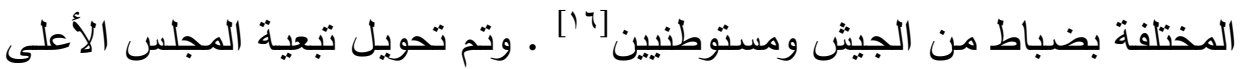
للتخطيط إلى إدارة حكوميـة في مكتب الثـئون الداخليـة بـالجيش. وألغيـت لجنـة تخطيط المنطقـة وتحولت صـلاحيات مجـالس الوحـدات المحليـة للقـرى للجهـاز المركزي للتخطيط. فلـم يتبـق للفلسطينيين مـن صـالاحيات سـوى مجـالس المـن. وحتى هذه تم تحجيم دورها بطرق شتى. ويلخص الجدول التالي الفرق بين تشكيل الجهاز التخطيطي العام والإسرائيلي. جدول r ـ مقارنة بين تشكيل الجهاز التخطيطي العام والإسرائيلي.

\begin{tabular}{|c|c|c|}
\hline الاسرائيلي & 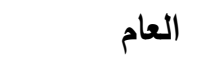 & الجهاز التخطيطي \\
\hline الجيش & 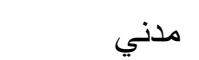 & 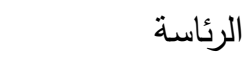 \\
\hline ممتلي سكان المستعمرات، التتظيم الصهيوني & فنيون، ممثلي & 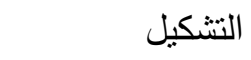 \\
\hline العالمي، ممثلي الوزرات & 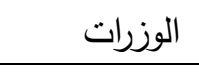 & \\
\hline شبه مطلقة & 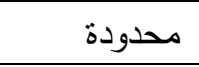 & الصلاحيات \\
\hline$\% \cdot-1$ & غير مدعوم & 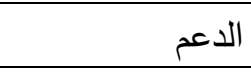 \\
\hline الخارج & موارد الدولة & التمويل \\
\hline
\end{tabular}

إن الإزدواجيـة هـي قـانون واحـد بطبـق بطـريقتين. فـرغم أن نفس النظـام المسؤول عن التخطيط في المناطق الفلسطينيّة هو نفسـه المسؤول عن التخطيط في المستوطنات، إلا أن المعـايير المطبقة على كل منهمـا مختلفة (ومتعارضـة) وئؤدي إلى مسارين مختلفين. ففي المسار الإسرائيلي، ترفع المخططات للتصديّق 
إلىى اللجنـة الفرعيّة للمسـتوطنات (إحـدى اللجـان الفرعيَّة في مجلس التخطيط

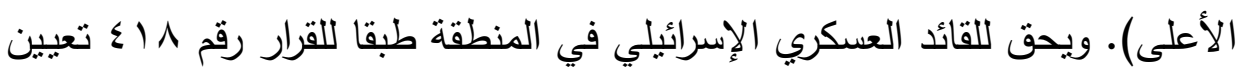

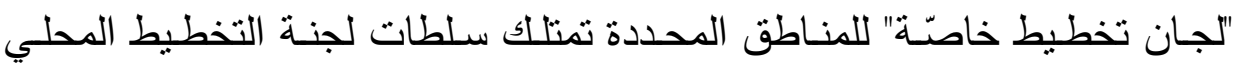
وكنلك سلطات لجنة تخطيط المنطقة. طبعا هذا البند يستعمل لخلق وحدات إدارية

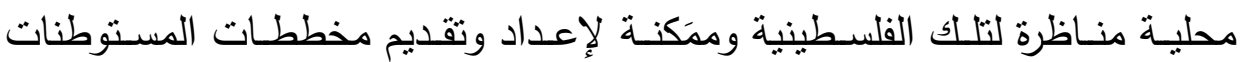
لمجلس التخطيط الأعلى ولمنح رخص البناء لسكّانها. وتسمى حدود المنطقة التخطيطية للمستوطنة (وبمعنى آخر : منطقة النفوذ القضائية) في الطلب الصادي التهاد

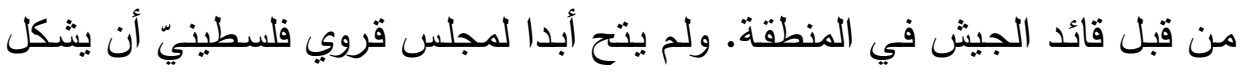
لجنة تخطيط خاصّة.

وتعـد الإدارات المحليّة اليهوديـة مخططاتها بالتعـاون مـع الإدارات المعنيـة

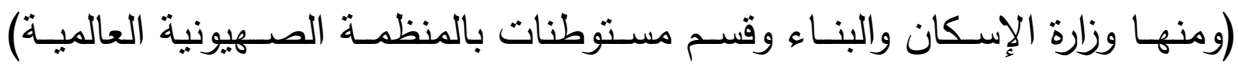

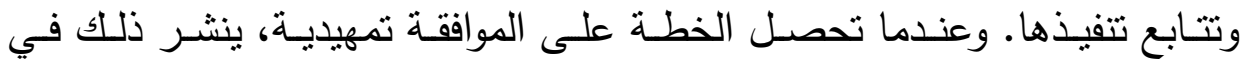

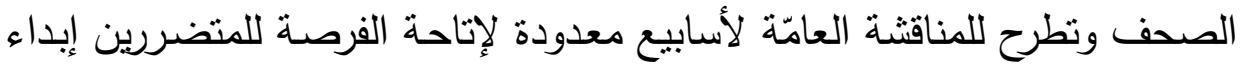

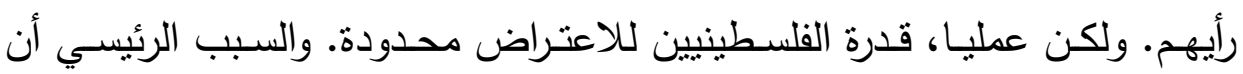

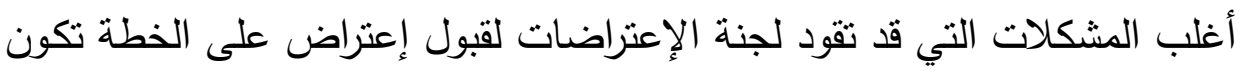

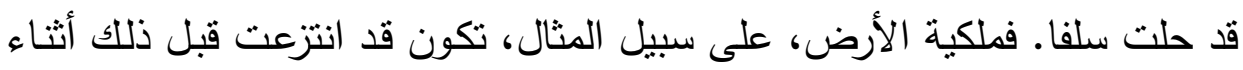

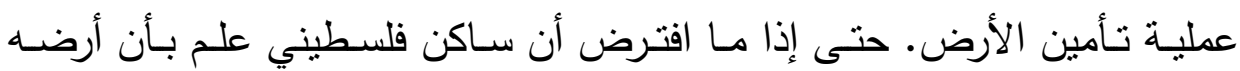

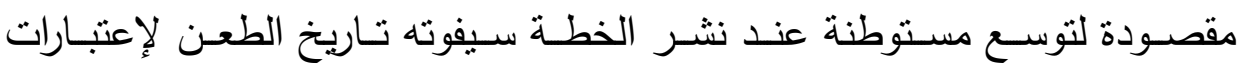

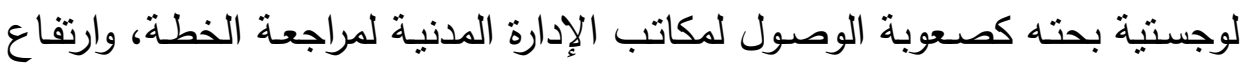
تكلفة تسجيل الاعتراض، وهكذا.

\section{هـ ملخص الأدوات التخطيطية المستخدمة في السيطرة المكانية}

يظهر مما سبق كيف تم استخدام سبع أدوات تخطيطية في السعي لتحقيق

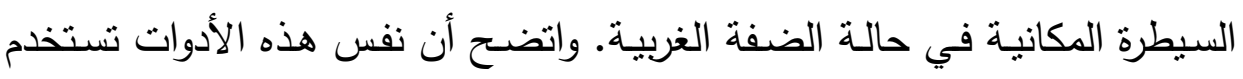

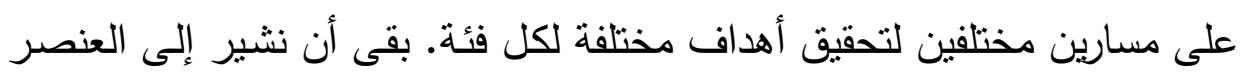


البشري الذي تعتبره إسرائيل سلاحا استراتيجيا في سيطرتها المكانية على الضفة. فكل تلك الأدوات مـا كان لها لتؤثز بغير حراك سكاني يواجه التقل الديموجرافي الفلسطيني. وذلك الحراك البشري معروف أن دوافعه الرزق والأمن والأيديلوجيـة. وقد وضحنا دور الأيدولوجية في تكوين حركة "كتلة المؤمنين" الاستيطانية. والأمن وفرته اتفاقية أوسلو (نظريا على الأقل). أما الأدوات الاقتصادية فتمنلت في الدعم الدوله

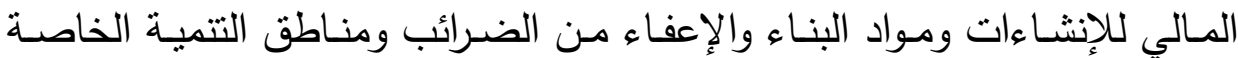
وغيرها من الوسائل التي تجعل كلفة الاستيطان أقل • بـ عن باقي المناطق. ويلخص الجدول ب التـالي الفـرق في دور تلكـ الأدوات عند اسـتخدامها التقليدي وعند استخدامها في فرض السيطرة.

جدول r. الفرق بين الدور التقليدي لأدوات التخطيط ودورها عند استخذامها في فرض السبطرة.

\begin{tabular}{|c|c|c|c|}
\hline الاستخدام الإسرائيلي لفرض & الاستخذام التقليدي & خصائص النمط المكاني في & الأكاة \\
\hline الالألتشار الاستراتيجي في أطراف & الدمم الأنثطة الاقتصادية السكاني & | منتشرة على الحدود وعلى القمم & $\begin{array}{l}\text { العمرانية } \\
\text { الجديدة }\end{array}$ \\
\hline 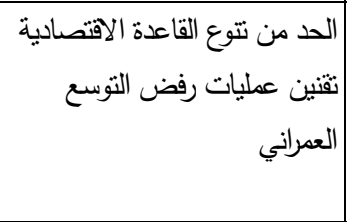 & الحراعتافة من تقارب الاستعمالات & 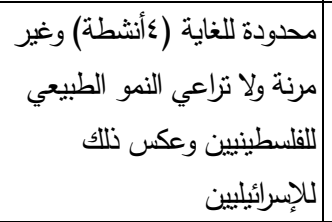 & r. \\
\hline |الضفناء صفة الثرعية القانونية & تنظيم العلاقات الادارية بين & | يدار عسكريا & 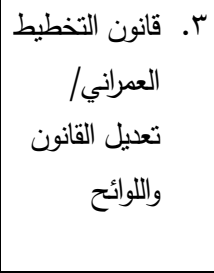 \\
\hline فرض |تحجيم النمو داخل الحيز & 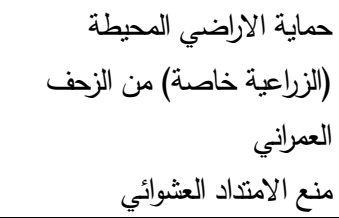 & |و لجصل بين المجالس الإقليمية & ع. ـ العديد الحيز \\
\hline
\end{tabular}




\begin{tabular}{|c|c|c|c|}
\hline ضزل مناطق أراضي بصورة غير قانونية & التطوي عليه من تقطيع لأواصل الأمن غير محبذ لمال & 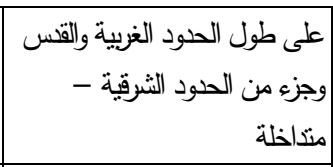 & 0. الجدران العدود \\
\hline 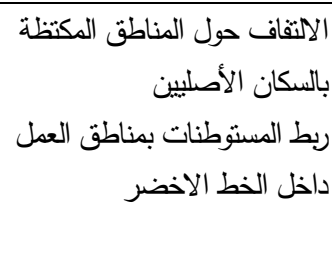 & تقلل من الازدحام ومن زمن النتمية بصورة فعالة & 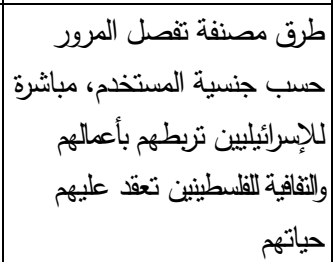 & ד. . شبكات الطرق \\
\hline خارج ضمان ولاء وشراء وتوسعة المستوطنات & منح امتنازات لمناطق يرجى التتمية إليها لمنفعة إقليمها & 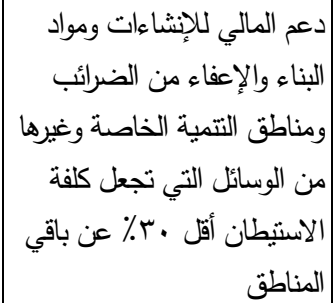 & 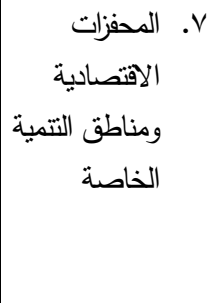 \\
\hline
\end{tabular}

ويمكن تلخيص حصيلة دور هذه الأدوات في تحقيق الأهداف الموضوعة

للسيطرة المكانية في المصفوفة التالية :

جدول ع. المصفوفة حصيلة دور الأدوات التخطيطية في تحقيق أهداف السيطرة المكانية.

\begin{tabular}{|c|c|c|c|c|c|}
\hline الإجمالي & الحقديق & الضصعاف & تالنمبيم & ومراقبة & التواصل \\
\hline 7 & $r$ & & $\nabla$ & $\nabla$ & च \\
\hline$\varepsilon$ & $r$ & & $\nabla$ & & 口 \\
\hline$\varepsilon$ & $r$ & $\nabla$ & & & ఐ \\
\hline 0 & $r$ & & $\nabla$ & $\nabla$ & 口 \\
\hline$r$ & $r$ & & $\nabla$ & & $\square$ \\
\hline 0 & $r$ & 口 & $\nabla$ & & च \\
\hline$r$ & $r$ & & $\nabla$ & & $\nabla$ \\
\hline \multirow[t]{2}{*}{$r$} & 1 & $\nabla$ & & & \\
\hline & & $r$ & 7 & $r$ & v \\
\hline
\end{tabular}

\begin{tabular}{|c}
\hline التخطيطية \\
\hline 1 \\
2 \\
3 \\
4 \\
5 \\
6 \\
8 \\
8
\end{tabular}

\begin{tabular}{|c|c|c|c|}
\hline ودرض ورجورافي & الانتشار & الوجيستي & محصلة \\
\hline$\nabla$ & $\nabla$ & $\nabla$ & $r$ \\
\hline$\nabla$ & $\nabla$ & & $r$ \\
\hline \multirow[t]{3}{*}{$\nabla$} & $\nabla$ & & $r$ \\
\hline & $\nabla$ & $\nabla$ & $r$ \\
\hline & $\nabla$ & & 1 \\
\hline \multirow[t]{2}{*}{$\nabla$} & $\nabla$ & & $r$ \\
\hline & $\nabla$ & & 1 \\
\hline$\nabla$ & $\nabla$ & & $r$ \\
\hline 0 & $\wedge$ & $r$ & \\
\hline
\end{tabular}

(5) (5) (5) الجدران والحدود العمرانية

(1) التجمعات العمرانية الجديدة

(6) نظام التخطيط العمراني

(2) (2) (3) المططات العمرانية

(7) نزع الملكية

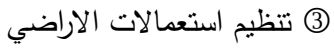

8) المحفزات الاقتصادية

(4) تخطيط شبكات الطرق 

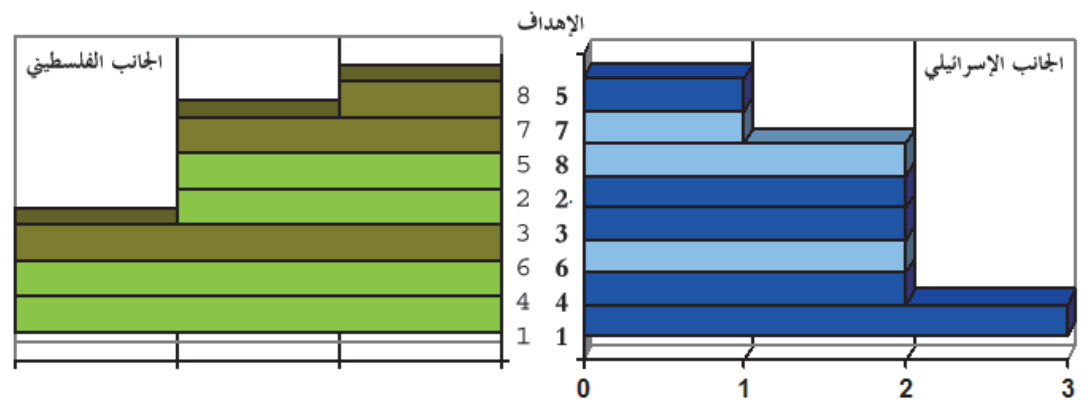

شكل بـ اـ هرم أهية أدوات السيطرة المكانية في تحقيق الأهداف المزدوجة.

\section{צ. نموذج السيطرة المكانية}

مدـا سـبق وطبقا لمـا أبرزتـهـ مصـفوفة تكـرار الأهداف في دراسـة الحالـة القلسطينية، فيمكن تطوير تصور عن منظومـة السيطرة المكانيـة باستخدام آليات التخطيط العمراني. كما يلي:

السيطرة المكانية هي محاولة لفرض وضع جغرافي يمييز فئة قوية على فئة أخرى مستضعفة بحيث يضمن للفئة الأقوى التفوق المكاني ويتحكم لأقصى درجة في المقدرات المعيشية للفئة الأضعف. وهو ما يجعل ممارسته تختلف عن إدارة النمو التي قد يجـادل البعض بأن مـا تمارسـة إسـرائيل هو نوع من ذلك. وبهذا التعربف نلاحظ أن من شروط تحول التخطيط من آلية لإدارة النمو والتتمية إلى هي أداة للسبطرة المكانية حدوث ما يلي:

ا ـ حدوث تقارب أيديولوجي وسياسي بين المخطط ومركز صنع القرار. r. وجود فئتين متصارعين غير متجانسين يعيشون جنبا إلى جنب في حيز

$$
\text { مكاني واحد. مان. }
$$

r. الانفـراد بتطويـع أدوات تمكـن المخطـط مـن التلاعـب فـي المقـدرات المعيشية لصالح الفريق الأقوى. ء. وجود نظام تخطيطي محكم ذو مرجعية قابلة للازدواج. 
وفي حـال توافر هذه الثـروط، يعمل التخطيط العمراني بأهداف مزدوجـة

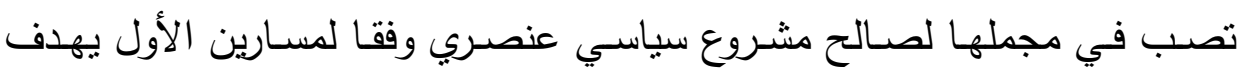

ا ـ منـع التواصل بين الكتل العمرانيـة باستخدام الطرق والتلاعب بالحدود

$$
\text { وغيرها. }
$$

r. تحجيم نموها السكني بشتى الطرق ومنها التطويق بالمستوطنات والعزل

$$
\text { بالجدر وغيرها. }
$$

r. حجب أو إضعاف الموارد الحيوية للفئة المستضعفة كالأرض والمياه

$$
\begin{aligned}
& \text { ع. مراقبة وتقييد الحركة. } \\
& \text { ويهدف الثاني إلى: }
\end{aligned}
$$

ا ـ تحقيق مبدأ الانتشار المكاني وتأمين مساحة وموارد للعيش. r. محاولة فرض واقع ديموجرافي وجيوسياسي يضمن استدامة السيطرة. r. توفير دعم لوجيستي لجيش الاحتلال.

وتنتخدم في تحقيق ذلك أدوات ترتب من حيث أهمية الدور الذي تلعبه (من الأهم للأقل)على النحو التالي:

التجمعـات العمرانيـة الجديدة - تخطيط شبكات الطـرق - نظـام التخطيط العمراني- تتظيم استعمالات الاراضي - المخططات العمرانية - الجدران والحدود العمرانية- نزع الملكية - المحفزات الاقتصادية.

وتتشأ مرتكزات السيطرة المكانية من خلال هذه الأهداف الأربعة. فالسعي لتحقيق السيطرة المكانية يشمل السيطرة على الموارد، والنمو، والتواصل، والحركة. فإذا مـا توافرت الرغبـة السياسية لتحقيق تلك السيطرة من خـلال القوة العسكرية، انعكس ذلك في وجود مباشر للقوات في تلك المواقع التي تحقق هذه الأهداف. أمـا 
وإن كـان التخطيط العمراني هـو الأداه المطلوبـة، فتسـتخدم أدواتـه وآلياته لـذلك. وطبعـا الميزة في تفضيل (وتفصيل) التخطيط للذلك هو الصبخة الثـرعية التي يضفيها هذا المنهج في كيان صورته الديمقراطية والمؤسساتية هي ركائز وجوده

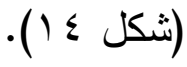

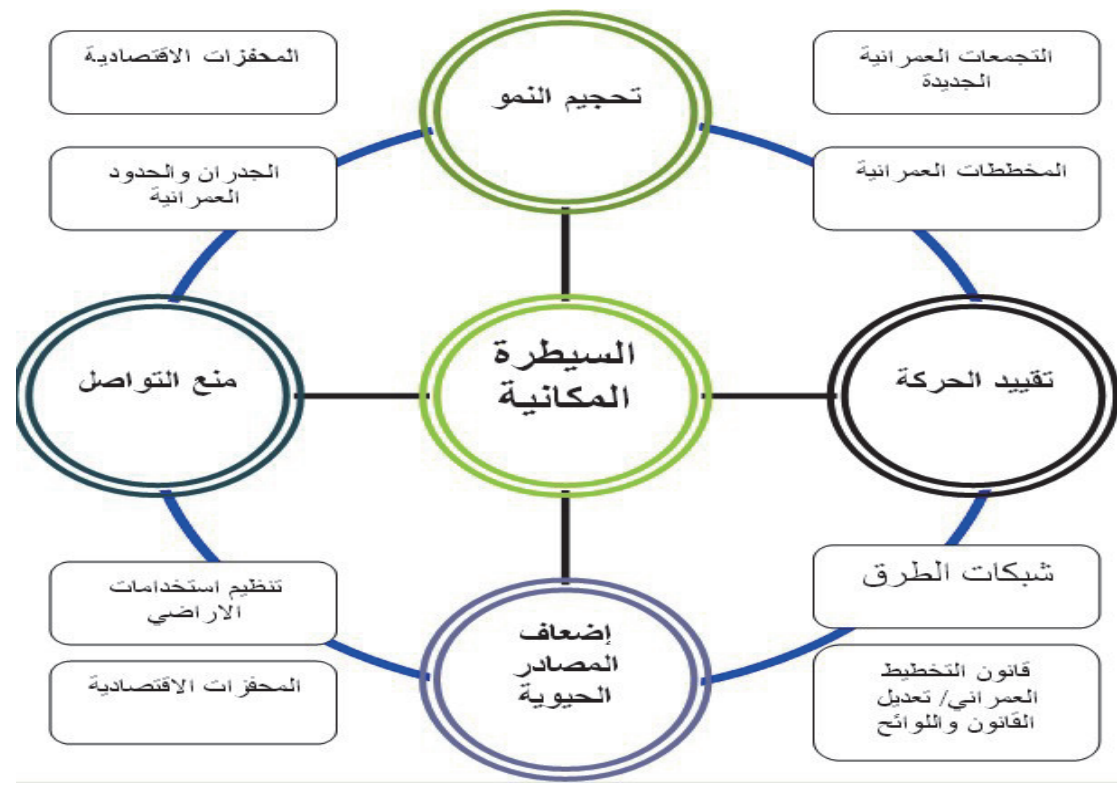

شكل ؛ 1 ـ ركائز السيطرة المكانية.

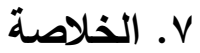

عرضت هذه الورقة كيفية تحول التخطيط العدراني إلى أداة تمبيز عنصري تسـتخدم نفس الأدوات والآليـات التقليديـة لتحقيـق "السـيطرة المطلقـة" و "السـيادة الفئوية" في نفس النطاق العمراني. وقد نتج عن دراسة حالة للضفة الغربية المحتلة ومقارنتها بما حدث في دولة جنوب إفريقيا من تطوير نموذج يبين ركائز السيطرة المكانية الأربعة وهي تقييد الحركة وتحجيم النمو ومنع التواصل وإضعاف مصادره 
و قد أبرزت هذه الورقة عدة نقاط:

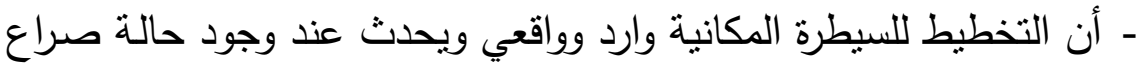
فئوي مكاني يتاح فيه للفئة الأقوى التحكم في الأدوات التخطيطية. - أن بعضا من الأدوات التخطيطية التي تستخدم في محاولة فرض السبطرة

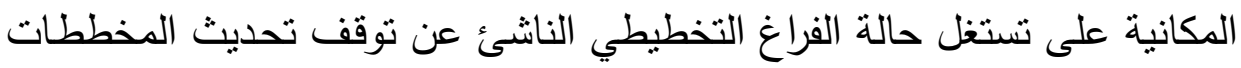
من جهة، وغياب تشريعات تخطيطية منصفة من جهة أخرى. - أن السيطرة المكانية التي لاتحقق قسرا بالطرق العسكرية (بالنواجد الفعلي للقوات على النقاط والخطوط الاسترايجية)، يمكن السعي لتحقيقها بأدوات التخطيط العمراني لتحقيق أهداف جيوسياسية تحجم النمو وتقطع التواصل وتحرم الاستفادة

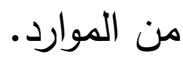

وعلى الرغم من خصوصية التخطيط العمراني تحت الاحتلال أو تحت النظم العنصرية، فنتائج هذه الدراسة قابلة للتعميم لاستتباط بعض التوصيات: فاستخدام نفس الأدوات بأهداف مزدوجـة وارد في أيـة حالـة تسيطر فيهـا

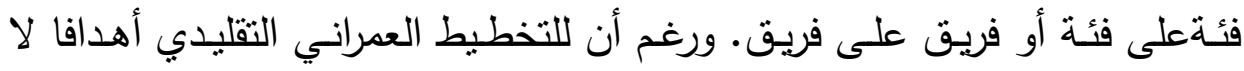

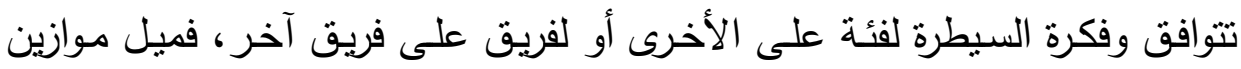

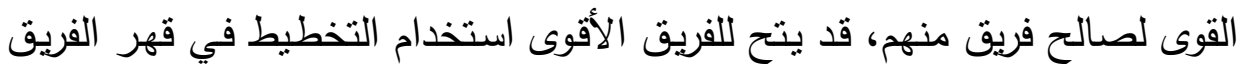

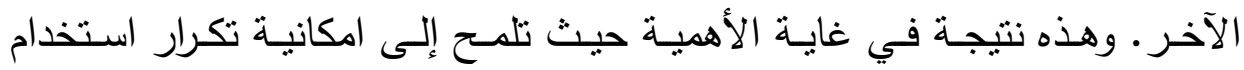
التخطيط للسيطرة المكانية الفئوية في دول أخرى بها تتوع عرقي أو أو ديني (كالعراق

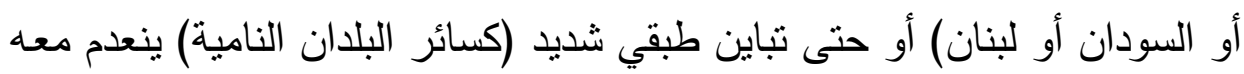

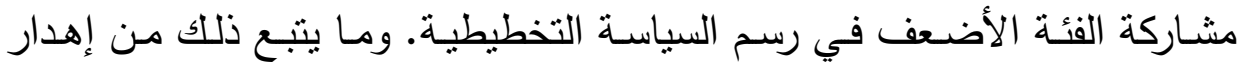
لنزاهة المهنة وتحطيم لأسس العدالة المجتمعية. عندها قد نكون أمام مخططات

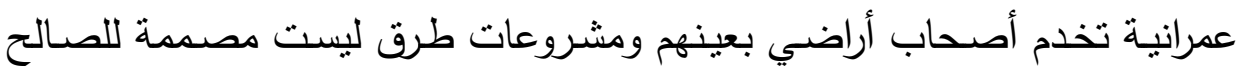
العام ومدن جديدة للمحظوظين فقط وهكذا. وعليه ولتجنب ذللك يوصى بما يليه بلئ 


\section{ا ـ مراجعة المنطلقات التي تقوم عليها التشربعات والهياكل التخطيطية. \\ Y. تحديد الفئات المهوثـة غيرالممثلة والعمل على اثـراكها مؤسسيا وفعليا في العملية التخطيطبة. \\ ب. مراعـاه التوازن المكاني في توزبـع الأنشطة والخدمات والمرافق بحيـث تتجانس النسب بقدر الإمكان مع فئات المستفبدين. \\ ع. الحد من ظاهرة الكنتونات الفئوبـة الآخذة في الانتشـار في كافة الدول \\ العربيـة وتأكيد تضــينها (إن كان لابـد مسن تواجدها) لمنـاطق إسـكان \\ متتوع الدخل في نفس الحييز المكاني. \\ ه. العدـل على دراسـة وكثـف حـالات السـيطرة المكانيـة المسـتخدم فيهـا
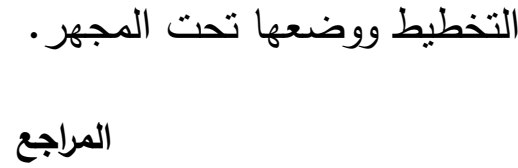

Frayne, Bruce (2000) "Political Ideology, Social Change, and Planning Practice in Namibia", Journal of Planning Education and Research, 20: 52.

Bremner, Lindsay (2005) Border/Skin in Against the Wall, edited by Michael Sorkin, The New Press - New York.

Frayne, Bruce (2000) "Political Ideology, Social Change, and Planning Practice in Namibia", Journal of Planning Education and Research, 20: 52.

Under the Rubble: House Demolition and Destruction of Land and Property, Amnesty International, May (2004) AI Index: MDE 15/033/2004.

Emunim, Gush (1980) Master Plan for Settlement in Judea and Samaria (in Hebrew).

Drobless, Matitiyahu (1980) The Settlement in Judea and Samaria - Strategy, Policy and Program (in Hebrew) (Jerusalem: World Zionist Organization, September.

Aronson, Geoffrey (1987) Creating Facts; Israel, Palestinians and the West Bank, Washington: Institute for Palestinian Studies.

Rotbard, Sharon (2003) "Wall and Tower", in: A Civilian Occupation: The Politics of Israeli Architecture, Rafi Segal and Eyal Weizman (ed.) Babel and Verso Publications. New York

Yiftachel, Oren (2002) The Power of Planning: Spaces of Control and Transformation, Edited by Oren Yiftachel, Kluwer Academic Publisher.

Segal, Rafi and Weizman, Eyal (ed.) (2003) A Civilian Occupation: The Politics of [1 •] Israeli Architecture. Babel and Verso Publications. New York.

Yiftachel, Oren (1996) The Internal Frontier: Territorial Control and Ethnic Relations in [11] Israel, Regional Studies, 30(5) August: 493 - 508. 
B'Tselem, LAND GRAB: Israel's Settlement Policy in the West Bank May (2002)

Lein,Yehezkel and Cohen-Lifshitz, Alon (2005) Under the Guise of Security Routing the Separation Barrier to Enable the Expansion of Israeli Settlements in the West Bank. Published by B'Tselem - The Israeli Information Center for Human Rights in the Occupied Territories and BIMKOM Planners for Planning Rights.

Sorkin, Michael (ed), (2005) Against the Wall, The New York Press.

Halabi, Usamah, Turner, Aron and Benvenisti, Meron (1985) Land Alienation in the West Bank: a Legal and Spatial Analysis, Jerusalem: The West Bank Data Project. 


\title{
Planning for Spatial Dominance
}

\author{
Ayman M. Ismail \\ Urban and Regional Planning, Faculty of Environmental Design, King \\ Abdulaziz University, Jeddah, Saudi Arabia
}

(Received: 04/12/2007, Accepted: 24/09/2008)

\begin{abstract}
Traditionally, among the noble goals of planning is the betterment of life in human communities through the spatial and demographic balance (both between activities or groups). Often associated with planning values in democratic systems is the equality between humankind, class justice in socialism. Insofar that, some planners have equated their roles to the defense lawyer representing the oppressed and marginalized in the face of market and capital forces. Planners have used and invented many mechanisms and tools to achieve these puritan goals such as, land uses zoning, to private property protection legislations, eminent domain, road planning, standardization of systems and other well known physical planning tools aimed at achieving overall public good and the advancement of society. However, what is less common is the use of planning to oppress, dominate, or to contain a group. It is also not clear how the same tools that are used for noble planning causes can be twisted to suit racial or ethnic ideology.
\end{abstract}

This paper shows how a purely technical physical planning system can be turned around to fulfill an apartheid-saturated political agenda. The same tools can be simultaneously used to achieve interest of a few and guarantee maximum spatial control of another. The concept and definition of spatial domination, its objectives and instruments is introduced and discussed. The role of each planning tool in achieving spatial control is researched through a case study of the occupied West Bank. The aim is to find a relationship between the use of physical planning tools and the aims of spatial domination and geopolitical control. The methodology reviews and compares the experience of planning in South Africa during apartheid and devised planning tools used for the imposition of spatial control. The paper tracks the status of planning in the West Bank in military, ideological and strategic eyes. Mechanisms and instruments used in trying to impose control tireless spatial even with the talk about peace. Finally the paper offers a conceptual model of the spatial domination, its components and objectives and shows how much each tool promotes spatial control. The paper relies on data from secondary sources because of the complexities of tracking data first hand in Palestine.

Keywords: Spatial control, urban planning, racial planning, planning tools, the occupied West Bank. 